OECD Economics Department Working Papers No. 142

\title{
Pension Liabilities \\ in the Seven Major Economies
}

Paul van den Noord, Richard Herd 
Economics Department

Working Papers

No. 142

\section{PENSION LIABILITIES \\ IN THE SEVEN MAJOR ECONOMIES}

by

Paul Van den Noord and Richard Herd

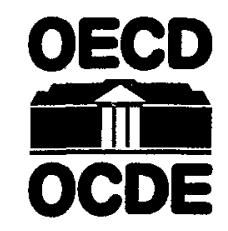

ORGANISATION FOR ECONOMIC CO-OPERATION AND DEVELOPMENT Paris 1993 
GENERAL DISTRIBUTION

OCDE/GD (93) 185

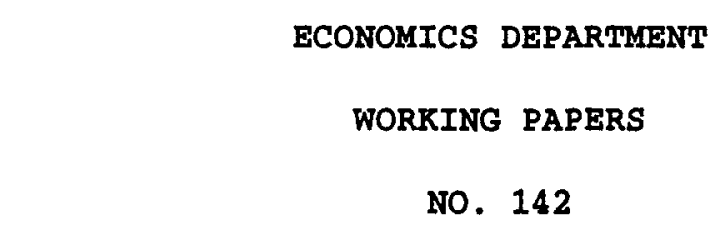

PENSION LIABILITIES IN THE SEVEN MAJOR ECONOMIES

by

Paul Van den Noord and Richard Herd

ORGANISATION FOR ECONOMIC CO-OPERATION AND DEVELOPMENT

Paris 1993

010696

FOR TECHNICAL REASONS, GRAPHS, TABLES \& FACSIMILES ARE NOT AVAILABLE ON OLIS 


\section{PENSION LIABILITIES IN THE SEVEN MAJOR ECONOMIES}

This paper forms part of on-going OECD work on the economic assessment of public pension systems in view of the process of the ageing of populations. It provides indicative estimates of the likely size of public pension liabilities in the main seven economies based on simplifying assumptions, and analyses various methods of financing these liabilities. The methodology developed here is based on the so-called generational accounts approach. Such accounts indicate in present-value terms the lifetime financial burden government programmes impose on present and future generations. Up to now, the methodology has been used to estimate public pension liabilities in France and Belgium, in the framework of the 1993 OECD EConomic Surveys for those countries.

Ce document fait partie d'un travail en cours à l'OCDE sur l'évaluation économique des systèmes publics de pension face au processus de vieillissement des populations. A titre indicatif, il fournit des estimations sur l'importance probable des engagements des systèmes publics de pensions dans les sept grands pays en s'appuyant sur des hypothèses simplifiées et analyse diverses méthodes de financement de ces engagements. La méthodologie qui est développée ici se fonde sur l'approche dite de la comptabilité générationnelle. Celle-ci indique en termes de valeur actuelle le fardeau financier que les programmes gouvernementaux imposent sur les générations présentes et futures leur vie durant. Jusqu'à présent, cette méthodologie a été utilisée pour estimer les engagements des systèmes publics de pension en France et en Belgique, dans le cadre des Études Économiques de 1'OCDE de ces deux pays.

Copyright OECD, 1993 


\section{Contents}

Page

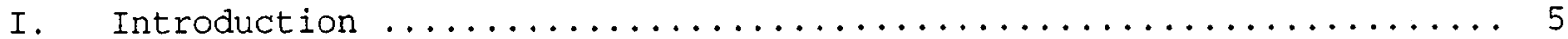

II. Public Pension Schemes and Expenditure $\ldots \ldots \ldots \ldots \ldots \ldots \ldots \ldots \ldots 6$

III. The Accrued Debt of Public Sector Pension Schemes ............ 9

IV. The Future Evolution of Benefits and Associated Liabilities ...... 16

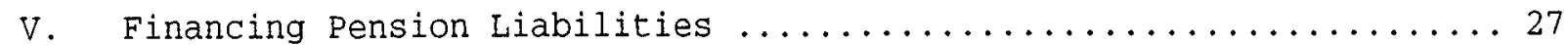

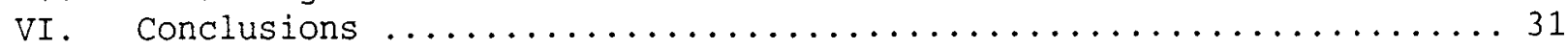

\section{Tables}

1. Public pension liabilities: present value of accrued rights $\ldots . \ldots 11$

2. Public pension liabilities: present value of accrued rights after a once-and-for-all increase in the discount rate by

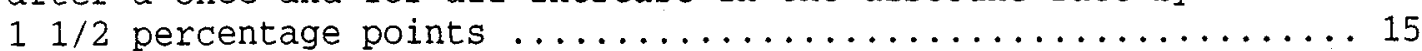

3. Annual average growth of population $\ldots \ldots \ldots \ldots \ldots \ldots \ldots \ldots \ldots \ldots$

4. Steady-state transfer and employment ratios ................. 20

5. Public pension liabilities: present value of current

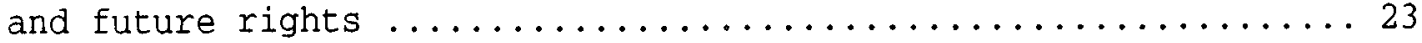

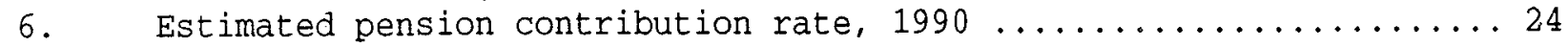

7. Estimated net pension liabilities: present value of current and future rights and future contributions .......... 25

8. Estimated net pension liabilities: present value of current and future rights and future contributions after a once-and-for-all increase in the discount rate

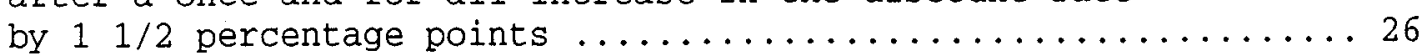

9. Alternative scenarios for financing pension liabilities ......... 28

10. Present values of inter-generational transfers from present children and the unborn to present retired and workforce

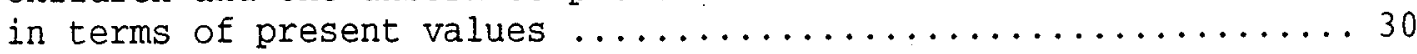

\section{Figures}

1. Cumulative growth in real pension expenditure and beneficiaries

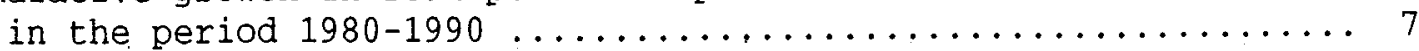

2. Pension expenditure relative to GDP and pension beneficiaries relative to the working population $\ldots \ldots \ldots \ldots \ldots \ldots \ldots \ldots . \ldots \ldots$

3. Ratio of pensions per beneficiary to GDP per worker $\ldots \ldots \ldots \ldots \ldots 10$

4. Conventional debt and pension liabilities as a percentage

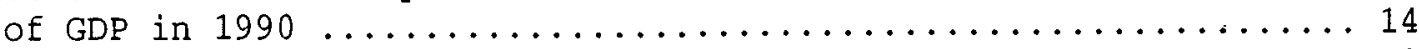

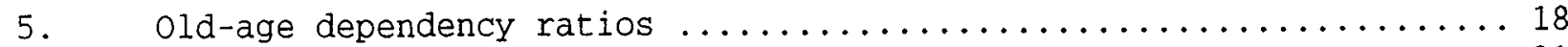

6. Projected ratios of pension expenditure to GDP $\ldots \ldots \ldots \ldots \ldots \ldots \ldots 21$ 


\section{Contents (cont'd)}

Page

Annex 1: Public Pension Systems in the Seven Major Economies .......... 35

Annex 2: The Valuation of Pension Schemes .................... 49

Annex 3: Financing Options for Pension Schemes ................... 57

Annex 4: Simulation of the Alternative Financing options ...........6 60

\section{Tables}

1.1. The pension formula for general old-age benefit schemes in the main seven countries ........................ 36

1.2. Public pension expenditure and beneficiaries

in the main seven countries ........................ 37

1.3. The cumulation of assets in funded schemes in Fiscal Year $1990 \ldots 38$

1.4. Public retirement pensions in the United States ...........42

1.5. Public retirement pensions in Japan $\ldots \ldots \ldots \ldots \ldots \ldots \ldots \ldots \ldots$

1.6. Public retirement pensions in Germany $\ldots \ldots \ldots \ldots \ldots \ldots \ldots \ldots . \ldots 4$

1.7. Public retirement pensions in France $\ldots \ldots \ldots \ldots \ldots \ldots \ldots \ldots \ldots \ldots$

1.8. Public retirement pensions in Italy $\ldots \ldots \ldots \ldots \ldots \ldots \ldots \ldots \ldots$

1.9. Public retirement pensions in the United Kingdom . . . . . . . . 47

1.10. Public retirement pensions in Canada $\ldots \ldots \ldots \ldots \ldots \ldots \ldots \ldots$

2.1. Generational account of present and future net pension

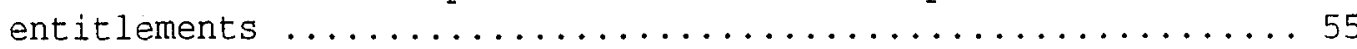

4.1. Generational accounts: the present value of pensions and contributions. The case of Pay-As-You-Go financing .......6 61

4.2. Generational accounts: the present value of pensions and contributions. Funding through a once-and-for-all

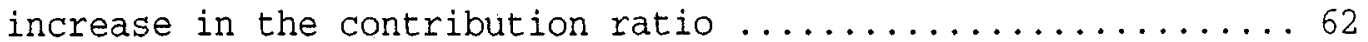

4.3. Generational accounts: the present value of pensions and contributions. A once-and-for-all reduction in the earnings elasticity of new pension benefits ............66 63

4.4. Generational accounts: the present value of pensions and contributions. The case of increased pensionable age ......64

\section{Figures}

2.1. Hypothetical accruals of pension rights before $1990 \ldots \ldots \ldots \ldots 51$

2.2. Hypothetical accruals of pension rights after $1990 \ldots \ldots \ldots \ldots$

3.1. The profile of pension benefits and contributions under various financing regimes (an illustrative case) ......... 58 


\title{
PENSION LIABILITIES IN THE SEVEN MAJOR ECONOMIES
}

\author{
Paul Van den Noord and Richard Herd (1)
}

\section{Introduction}

Future entitlements of people insured under public pension schemes are not included in the most commonly-used measures of public-sector financial positions, even though there are recent cases where government departments have attempted to make estimates of future entitlements in the framework of so-called Generational Accounting projects (2). However, there is increasing concern that public finances will be subjected to enhanced pressure from the scale and financing requirements of public pension schemes -- in particular in the light of ageing populations projected for most OECD countries. The aim of this paper is to illustrate the extent of the problem by presenting estimates of the likely size of public pension liabilities in the major seven OECD economies and analysing various methods through which these liabilities might be financed (3). While the results are only indicative, in particular because many simplifying assumptions have had to be made; they strongly support the conclusion that financing of public pension systems may well increasingly complicate the achievement of sound public finances.

After a brief review of the public pension systems in the countries under consideration (Part II), estimates are given of liabilities related to: accruals of pension rights up to 1990 (Part III), and new accruals and new entrants in later years (Part IV). In Part V, four ways to finance the liabilities are considered: i) continuing or reintroducing Pay-As-You-Go financing (matching future flows of pension contributions and pension expenditures on a year-by-year basis); ii) a once-and-for-all increase in pension contribution rates (4); iii) partial rather than full uprating of assessed past earnings (on which individual pension rates are based); and iv) an increase in the minimum pensionable age. More country detail on public pension systems and the associated data on which the analysis is based is presented in Annex 1. In Annex 2 the methodology used in this paper is compared to the pension valuation systems that are generally used in the private sector. While the main text focuses on the stocks of assets and liabilities of the public pension schemes under consideration, Annex 3 assesses the typical time profile of future flows (contributions, benefits and financial balances) associated with each of the four financing options, and Annex 4 the associated intergenerational transfers. 


\section{Public Pension Schemes and Expenditure}

\section{The basic features of public retirement schemes}

\section{The scope of the systems}

All countries have various types of public pension schemes. Basic coverage for all residents is provided by general schemes, with the same rules applying to all, irrespective of the industry of employment or the employment status (salaried worker, self-employed, etc.). Pensions under general schemes may be either earnings-related or flat-rate, or a combination of the two, and may be means-tested or supplemented by means-tested benefits. The retirement age is fixed in all countries, but there typically exist provisions for early or deferred retirement at actuarially adjusted pension rates. other schemes, with less comprehensive participation than the general scheme, may provide additional coverage to specific sectors of the population or the labour force. The financing and administration of these schemes may be separate from the government, even though participation is mandatory and financial transfers across the various schemes sometimes occurs.

\section{The pension formula}

The pension benefit granted when an individual claimant enters retirement is usually fixed according to some legal formula, defining his assessed past earnings on which the pension is based (where the pension is earnings-related), the number of contribution years that are taken into account and the way in which entitlements cumulate per year of contribution (or per year of employment). The assessed earnings to which the replacement rate is applied when a person enters retirement cover the best ten years in France (to be gradually increased to the best 25 years under the recent reform) and the last five years in Italy and longer periods in the other countries. Early retirement is typically granted at some reduced pension rate, provided that a minimum pensionable age and a minimum number of contribution years have been attained. Deferred retirement is generally possible at an actuarially augmented pension rate, conditional upon a maximum pensionable age and a minimum number of contribution years. Assessed earnings are usually uprated in line with increases in overall earnings over a worker's career. In subsequent years of retirement, the pension rate is normally adjusted for overall increases in the cost of living. In flat-rate schemes, the pension rate is independent of past earnings, but may nonetheless vary with the number of contribution years, and for various types of beneficiaries (family heads, dependent spouses, etc.). Three countries (Japan, the United Kingdom and Canada) have a mixture of both flat-rate and earnings-related schemes.

\section{The financing of the schemes}

Government expenditure for public retirement pension schemes is financed on a Pay-As-You-Go (PAYG) basis for five of the major seven countries, the United States and Japan being exceptions. This mode of finance implies that pension expenditure and pension contributions in any (fiscal) year have to balance, requiring present contributions to match the pension benefits of those currently retired. PAYG has been adopted in the post-war period because it allowed governments to build up public pension systems without the typical 
Figure 1. Cumulative growth in real pension expenditure and beneficiaries in the period 1980-1990

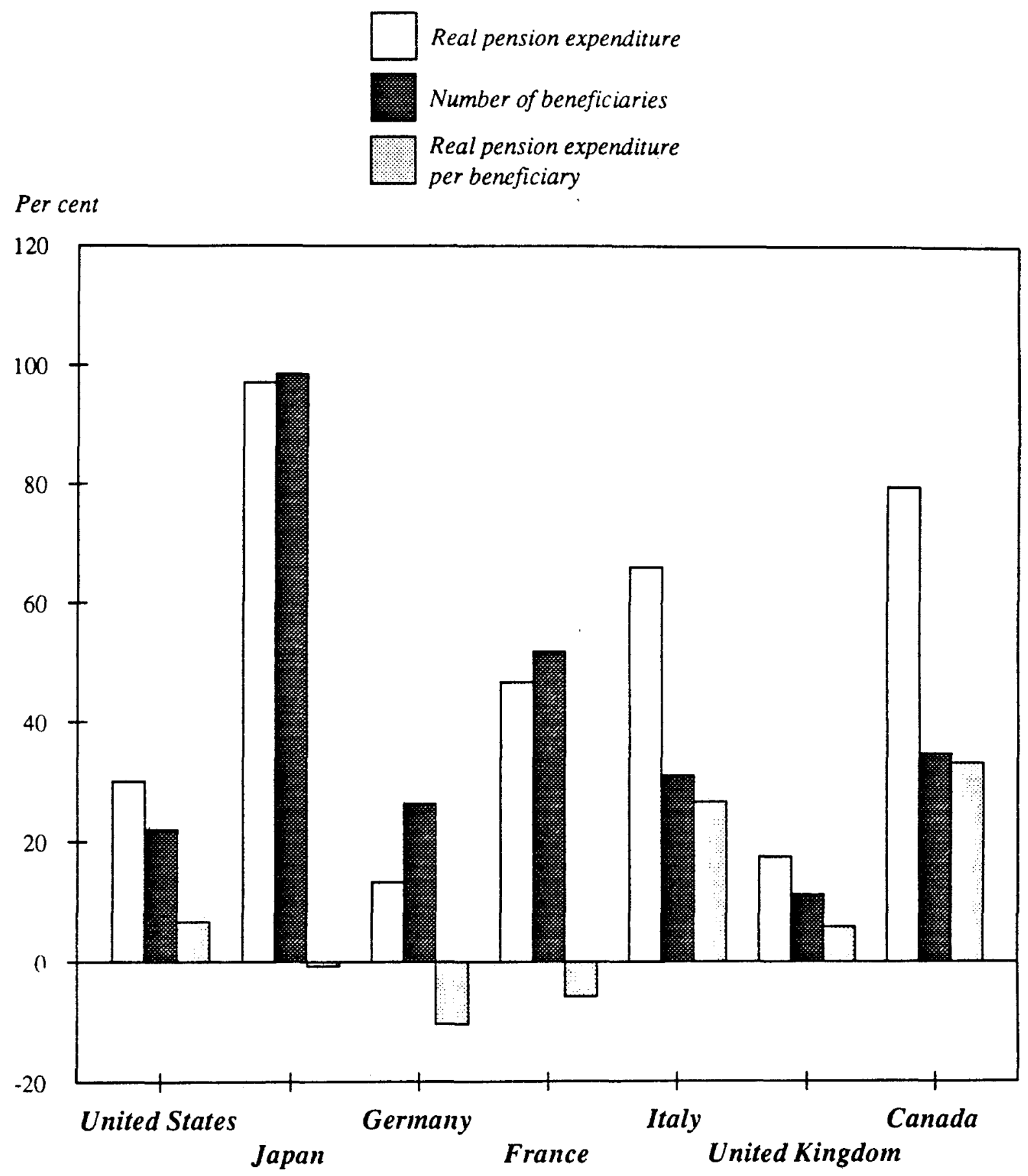


Figure 2. Pension expenditure relative to GDP and pension beneficiaries relative to the working population
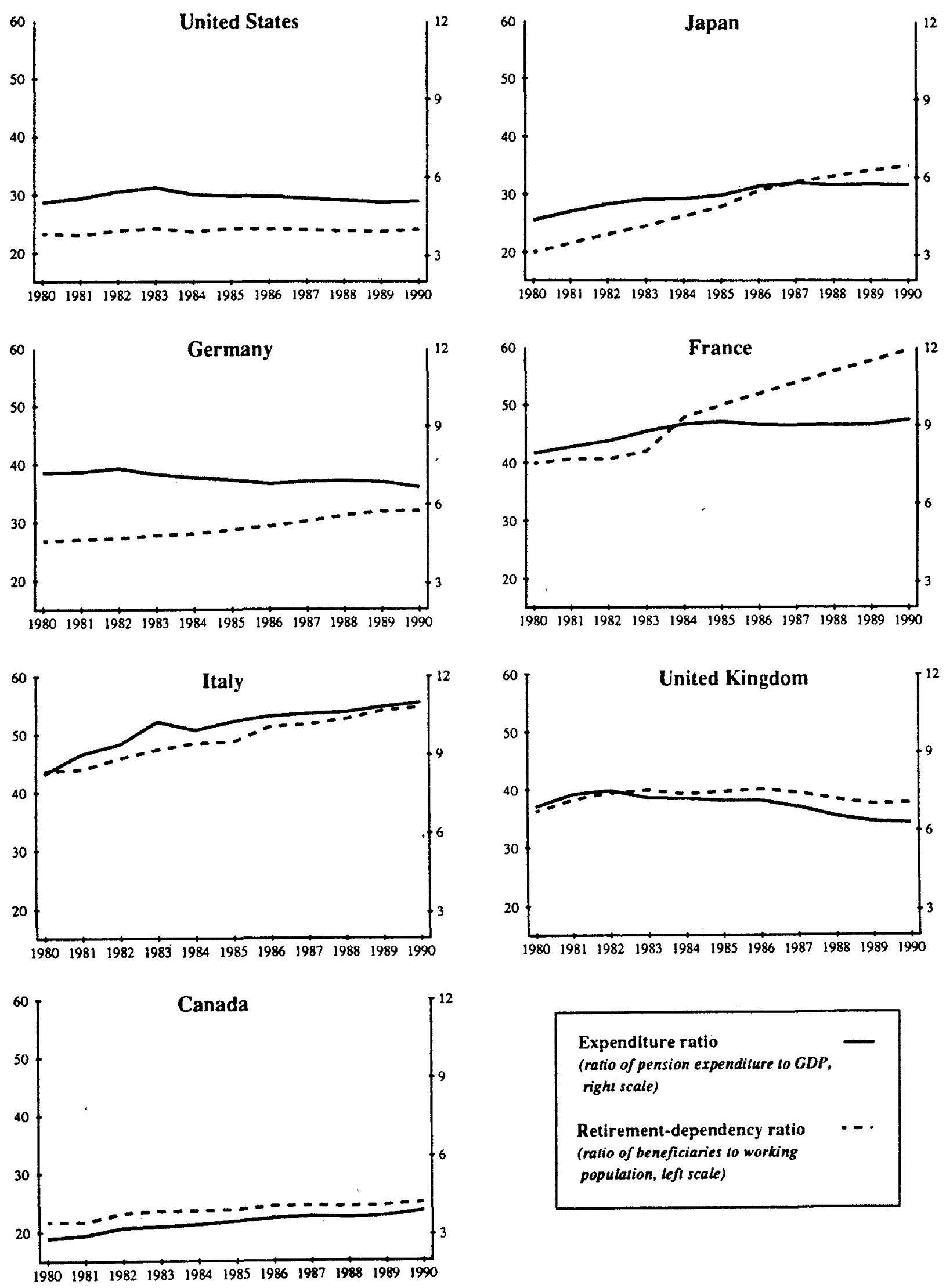
phasing-in lags involved in fully-funded schemes. In general, retirement pensions were immediately granted to all present retired, irrespective of their past contributions. In funded systems, of the kind the United States and Japan have implemented, expenditure and receipts have to be matched over the life-span of the scheme but not necessarily within one (fiscal) year. When a pension fund is created, all members are working and contributing. As a result, financial assets are gradually built up, until the payment of benefits equals the sum of contributions and the return on the fund's assets. The return on the fund's assets reduces the total required amount of contributions relative to what would have been involved in PAYG (5).

\section{Pension expenditure in the $1980 \mathrm{~s}$}

Real pension expenditure has increased steadily since the Second World War; this trend persisted in the 1980s despite various reforms in public pension schemes (Figure 1) (6). However, there are important differences across countries. Growth in pension expenditure has been particularly strong in Japan (where it has almost doubled), in Italy and Canada (where it has risen by over 60 per cent) and in France (where it rose by over 40 per cent). In Germany, the United States and the United Kingdom, on the other hand, real expenditure increased by only around 20 per cent. Such growth has resulted in a ratio of pension expenditure to GDP (Figure 2) that ranges from below 4 per cent in Canada in the late 1980s to 9 per cent in France and over 10 per cent in Italy.

The growth in expenditure reflects various factors. In Japan, the rise in pension expenditure is mainly due to enhanced coverage through the introduction of a new basic flat-rate system, which has led to new categories of beneficiaries receiving pensions (See Annex 1). Real pension expenditure per beneficiary in Japan has remained virtually constant (Figure 1). In France, too, the number of beneficiaries has risen substantially, especially due to a greater use of early retirement that has subsequently been partially reversed. Only in Italy and Canada has the rise in pension expenditure been accompanied by a significant rise in average real pension rates, of the order of 25-35 per cent. The situation in Canada, however, has to be judged against the relatively low pension rates at the beginning of the decade and reflects the maturing of recently created earnings-related schemes (Annex 1). More generally, during the 1980s, the ratio of real pensions to real GDP per worker in the major seven countries has converged steadily (Figure 3 ).

\section{The Accrued Debt of Public Sector Pension Schemes}

Public pension entitlements are a liability of the government as contributors expect their acquired pension rights to be honoured. In this section of the paper, a technique to calculate current liabilities -- i.e. to calculate the present value of accrued entitlements -- is presented and applied. Government liabilities stemming from accrued pension rights in the major seven economies, based on a number of simplifying assumptions, are estimated to range from one to two-and-a-half times 1990 GDP, with around 


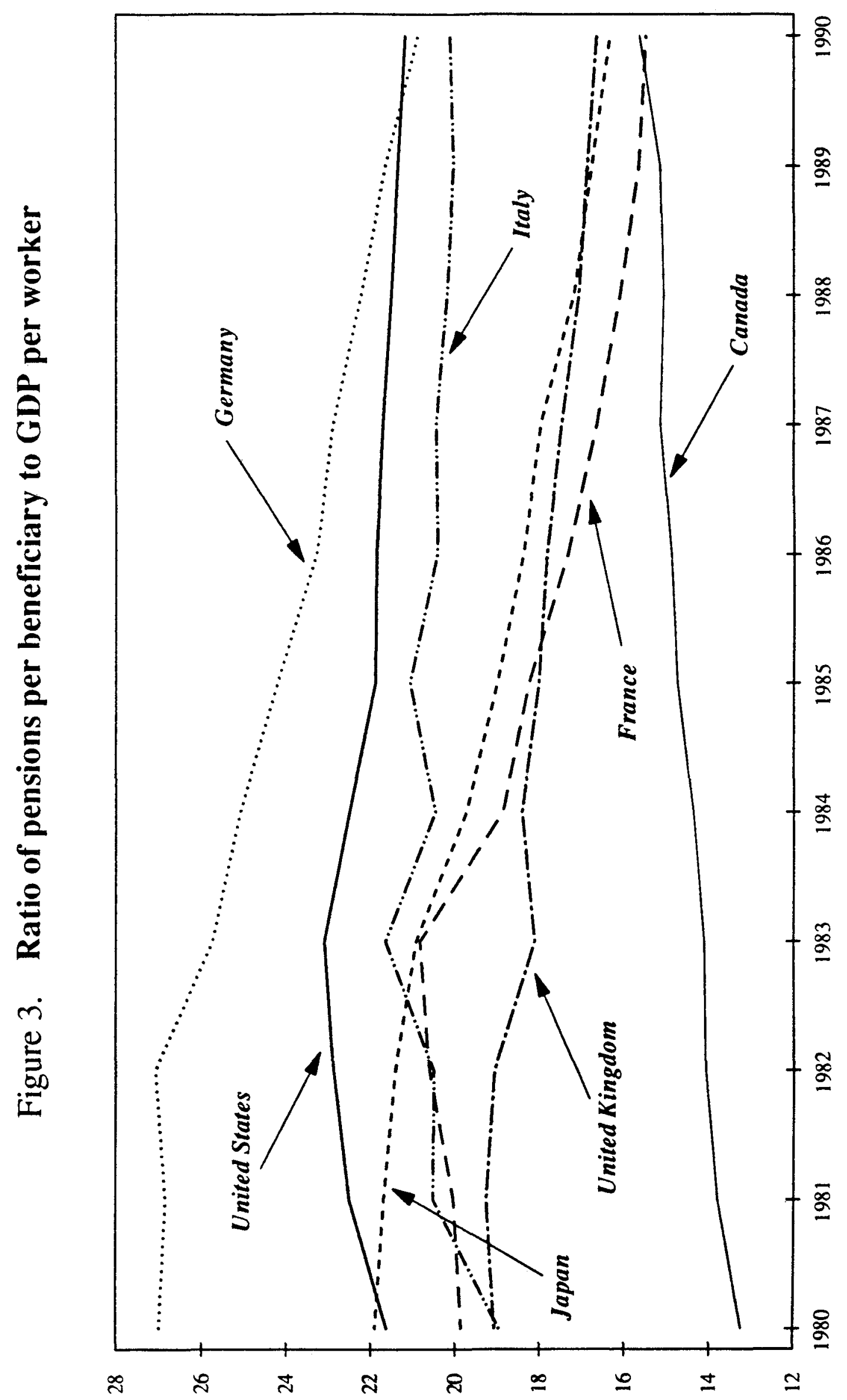




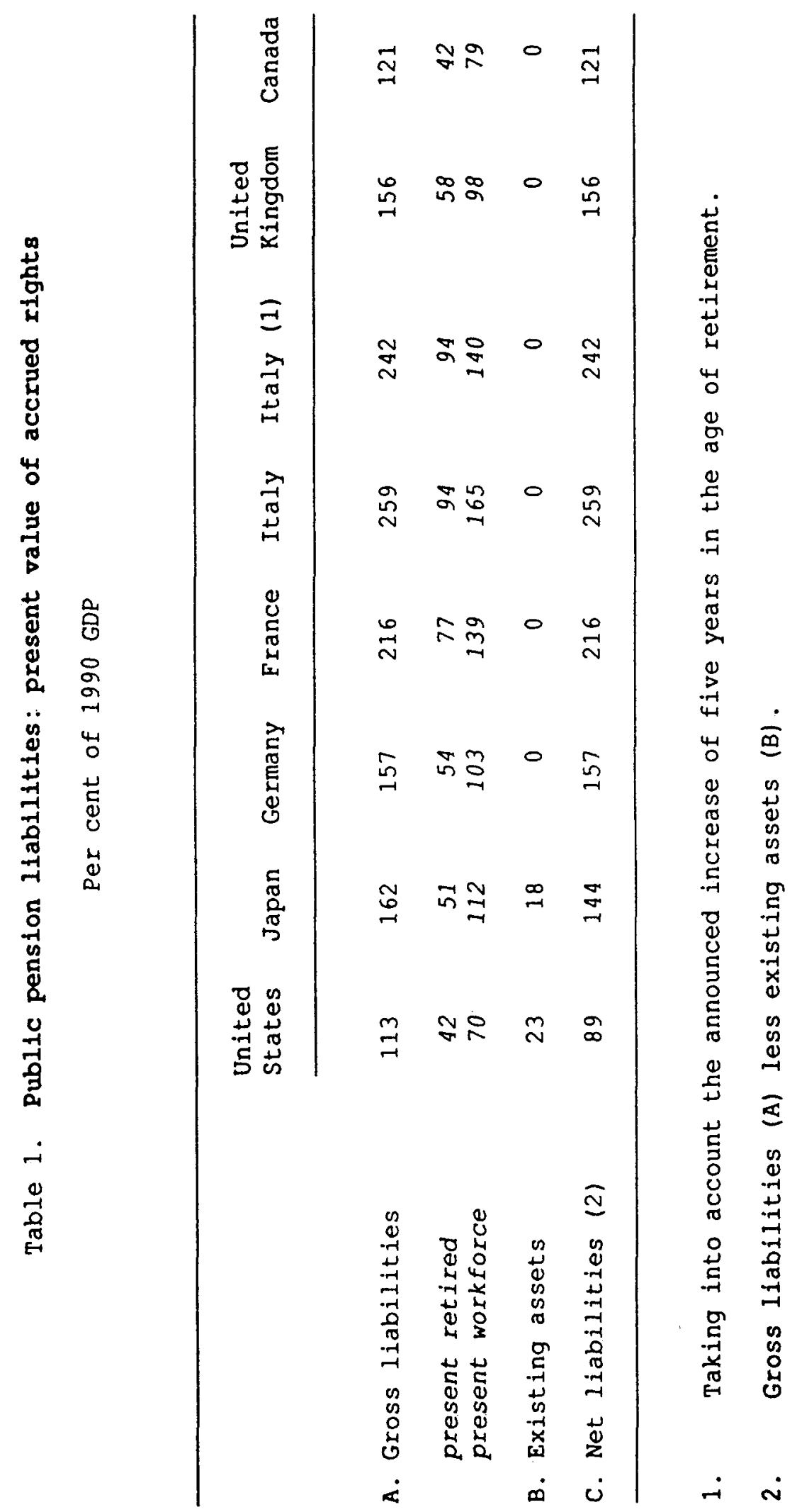


two-thirds of the total representing the accrued rights of the present workforce (Table 1).

\section{The assumptions}

The results summarised above are based on a number of quite strong assumptions. These assumptions, which are discussed at length in Annex 2, relate to the real discount rate, economic and population growth and the future rules of the pension schemes. As has been discussed in the preceding section, there are substantial differences between countries concerning the scope of public pension systems and the degree to which pension benefits are related to the earnings history of the claimants. For the sake of simplicity, however, uniform assumptions across countries have been made with respect to these aspects, representing a "typical system" in the countries under consideration.

More specifically, the typical retirement age is assumed to be 60 , with 40 contribution years being required for a full pension. In addition, a flat accrual factor of $1 / 40$ per annum has been assumed. The real pension rate a person is entitled to when he enters retirement is assumed to be a fixed percentage of overall real earnings -- except in the United Kingdom and Canada, where real pension rates reflect the progressive maturing of the relatively recent earnings-related schemes. The real pension rate is subsequently held constant over the retirement age. These rules are assumed to apply to males and females, family heads and dependent persons, wage-earners (private and public sector), self-employed and non-employed persons alike. This system is calibrated on data for 1990 so as to obtain the appropriate initial values for pension rates, the number of retired persons per age group (eligibility ratios), etc.

As the projected future stream of pension transfers will have to be converted into a present value, a projection has to be made of the discount rate. With all projected money flows given in constant prices of 1990 , the real rather than the nominal discount rate has to be projected. Two paths of real interest rates have been used. The first path assumes, conservatively, that the real discount rate is 4 per cent for the period 1990-2010 -- around the current average, real long-term interest rate in the major seven countries (7). It is thereafter allowed to drop stepwise to 3 per cent in 2050 (the last year of the simulation, when the last cohort with accrued rights up to 1990 is assumed to die). The second path assumes, perhaps more realistically, that the real discount rate is $11 / 2$ percentage points higher than in the first case, throughout the projection period.

In the long-term projections the choice of an appropriate discount rate is difficult. Real government bond yields have exceeded the rate of growth of earnings by large amounts in the last decade, after a period in which they were relatively low, bringing real yields more into line with those seen in the nineteenth century (8). The first path for interest rates is based on the view that long rates will move back to their average since 1800 (9), while the second assumption treats the period between 1930 and 1980 as an exception and so keeps the real discount rate relatively high and more in line with recent returns of private pension funds (10). The recipients of pension benefits may see future benefits as risk-bearing assets more akin to equities than to government bonds in which case the rate of discount should be slightly above 
6 per cent, reflecting the average return on equities (11). Others, though, have argued that discount rates should reflect the growth of earnings (12) or should be lower than capital market returns due to the rationing of social-security annuities (13).

\section{The results}

Pension liabilities are highest in Italy and France, at about two-and-a-half times and twice GDP respectively. The recent decision by the Italian Government to increase the pensionable age by five years is estimated not to have a significant impact, as it is assumed to affect primarily younger age brackets with small accrued rights to date. The change in accrual rights for the French pension scheme has not been taken into account. In the United States and Canada the estimated pension liabilities are relatively small, at about the same. level as 1990 GDP, reflecting a combination of low rates of retirement of people below 65 years of age, low pension levels and a favourable age composition of the population (see Part IV).

In the United States and Japan, pension liabilities are partially offset by financial assets held by public pension schemes (Table 1, line B). In the case of the United States, these assets cover more than half the entitlements of current retired persons, and about one-fifth of total liabilities. In Japan, the offsetting impact of financial assets is substantially smaller but still significant. It should be noted, though, that all of the assets in the United states are federal bonds: the U.S. social-security pension fund does not improve the sustainability of U.S. government policies to the extent that it is used to finance a federal government deficit on other items.

The estimated pension liabilities, on average, are about twice as large as conventional debt (Figure 4). Moreover, countries with a high debt to GDP ratio (either gross or net) also tend to have a high ratio of pension liabilities to GDP. In the case of Italy, in particular, the very high public debt ratio is accompanied with large pension liabilities. On the other hand, the United States, Japan, Germany, the United Kingdom and Canada have both relatively lower debt and pension-liability ratios. Public debt and pension liabilities in Germany, however, may have changed after unification. France is relatively unusual, in that it combines a relatively small public debt with relatively large pension liabilities.

The results appear not to be very sensitive to alternative assumptions on the discount rate. If the level of the discount rate is raised by $11 / 2$ percentage points the gross liability falls by around one-fifth (Table 2).

\section{Conclusions}

Accrued rights related to public pension schemes represent a government liability largely exceeding conventional public debt. The financial assets held by pension funds in the United States and in Japan, imply some relief of future pension financing requirements to the extent that these funds have not been used to allow deficits to increase in the remainder of the government sector. The situation in Italy is particularly striking, as it combines large 


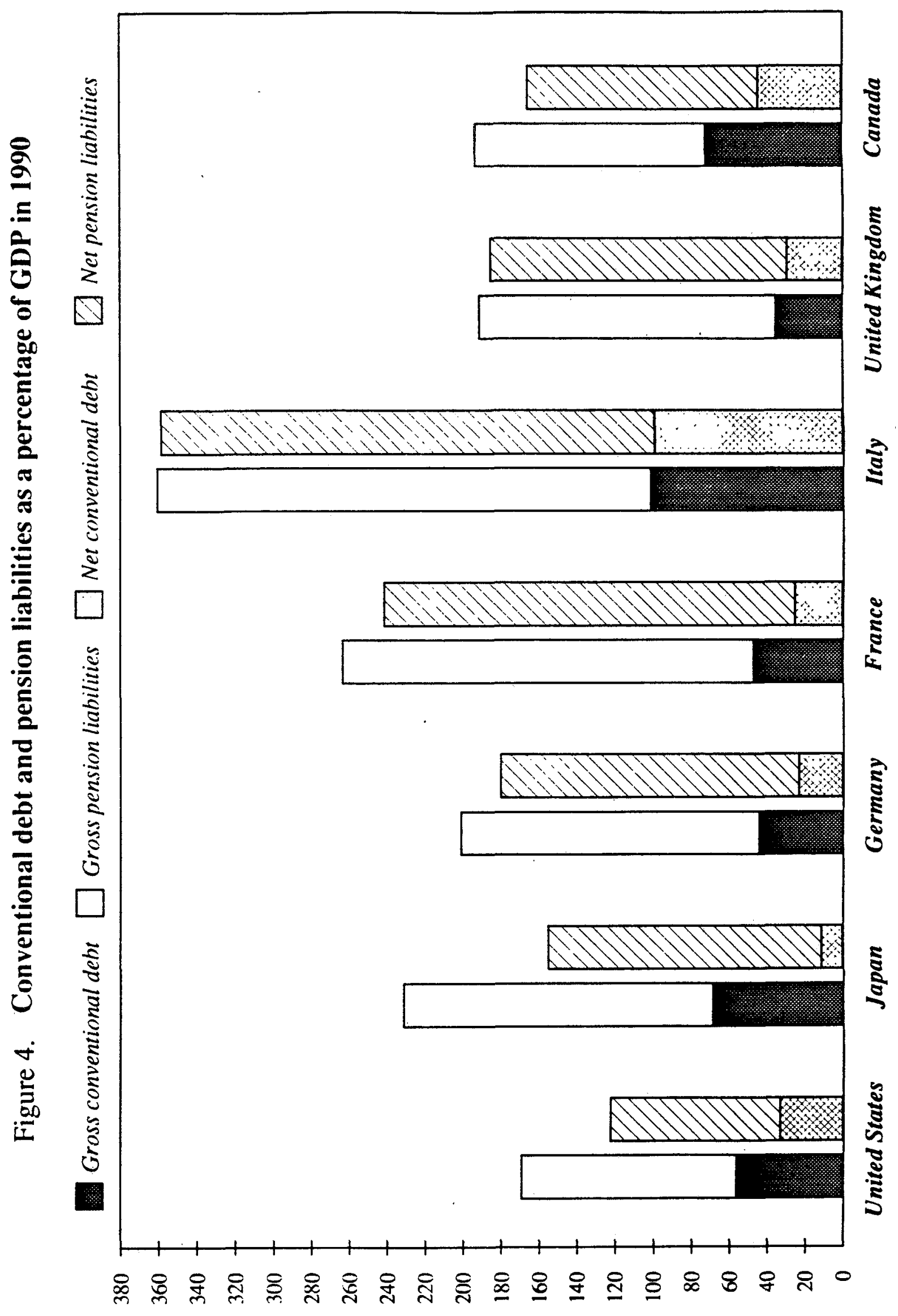




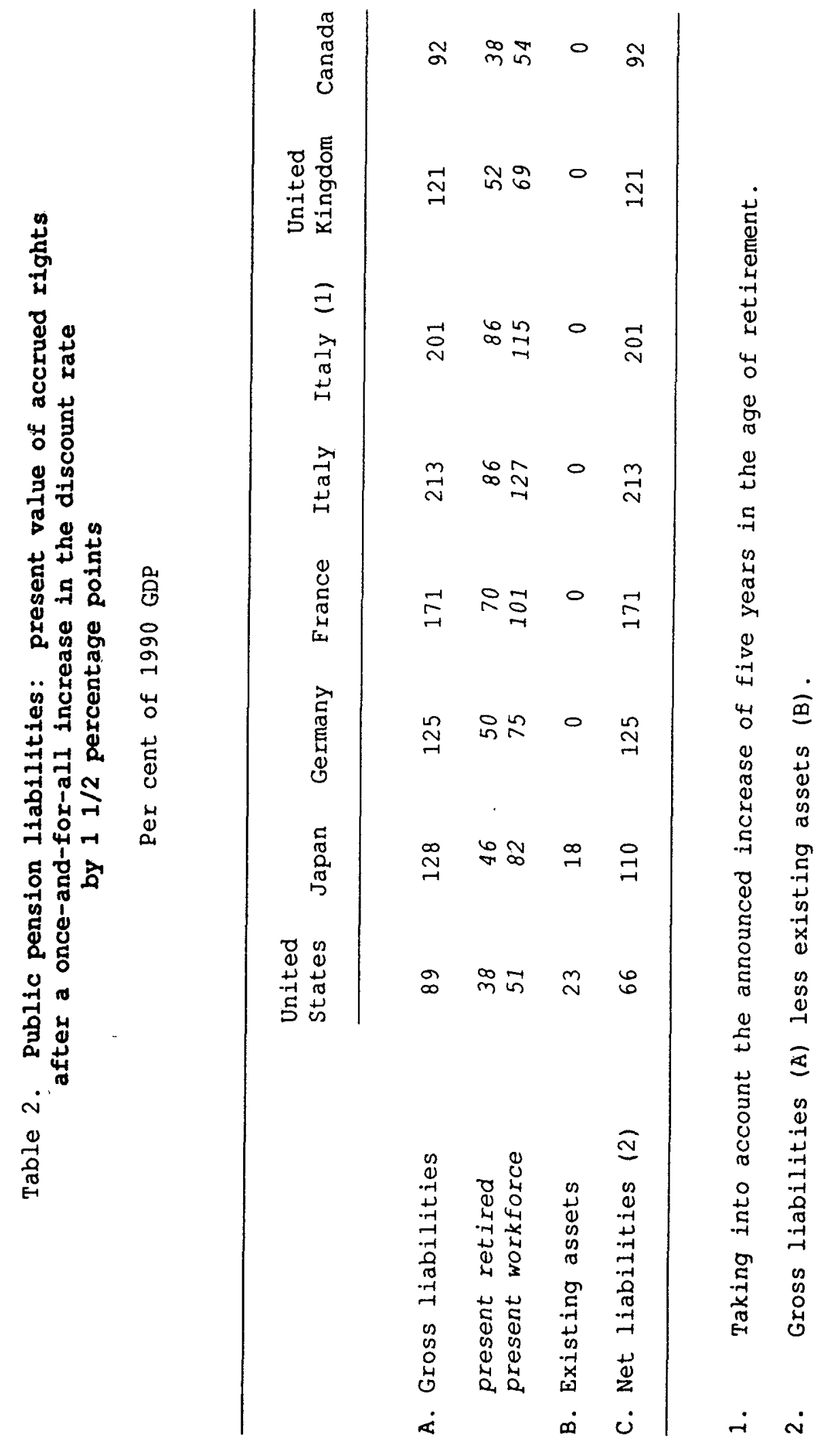


pension liabilities with a very high public debt. The announced increase in the pensionable age is unlikely to change this setting dramatically, as only the younger cohorts of the present workforce with only small accrued rights will be affected.

\section{The Future Evolution of Benefits and the Associated Liabilities}

The estimates presented in the previous part are restricted to accrued pension rights to date. However, the present workforce will continue to accrue new pension rights in the future, and future generations, both today's children and the yet unborn may be presumed to accrue such rights as well. At the same time, the present and future workforce will make pension contributions -- the present value of which may be considered as an "asset" of the government. These, admittedly, very uncertain future developments are quantified in this part. First, estimates are given of future pension expenditures, and the associated present values, for cohorts living up to the year 2160. This is followed by an estimate of future pension contributions by these cohorts -- assuming that present contribution ratios to GDP will be sustained forever -- and their present value. Finally, an estimate is made of the inter-generational distribution of pension entitlements and contributions.

\section{An estimate of future pension liabilities}

\section{Assumptions}

The future development of pension expenditure depends on the number of retired people relative to the number of people of working age (the old-age dependency ratio), together with the share of the retired people who receive pensions (the eligibility ratio), the ratio of those working to the total population of working age (the employment ratio) and the size of the average pension relative to the average output of those who are working (the transfer ratio) (14). The projections follow the same methodology as the calculations discussed in the previous part (See Annex 2).

The old-age dependency ratio is the primary determinant of the time profile of the expenditure ratio. It is based upon a demographic projection taken from the latest World Bank Development Report (15) and envisages a stable population in all countries by 2030, after a sustained slowdown in the rate of population growth in line with the trend since 1965 (Table 3) (16). International migration rates are based on past and present trends in migration trends and policies, but net migration rates are assumed to reach zero by 2025 (17).

According to the projections, all countries under consideration will show a sharp rise in the old-age dependency ratio in the next 40 years (Figure 5). The situation is particularly serious in Italy, western Germany and Japan, where the old-age dependency ratio is projected to more than double, moving well above the dependency ratio, before declining to a ratio typical of a stationary population. In the other four countries, the dependency ratio will increase, but is not expected to rise temporarily above its very long-term equilibrium. 
Table 3. Annual average growth of population

Per cent

$\begin{array}{ccccc}1965-80 \quad 1980-90 \quad 1990-2000 \quad 2000-30 \quad 2030-2160 \quad & \text { Level in } \\ & & 1990 \\ & \text { (millions) }\end{array}$

\begin{tabular}{lcccccc} 
United States & 1.0 & 1.0 & 0.9 & 0.6 & 0.0 & 252 \\
Japan & 1.2 & 0.6 & 0.3 & 0.0 & -0.1 & 124 \\
Germany & 0.3 & 0.3 & 0.2 & -0.1 & -0.1 & 63 \\
France & 0.7 & 0.5 & 0.4 & 0.2 & 0.0 & 56 \\
Italy & 0.5 & 0.2 & 0.1 & -0.2 & -0.1 & 57 \\
United Kingdom & 0.2 & 0.2 & 0.3 & 0.2 & 0.0 & 57 \\
Canada & 1.3 & 1.0 & 1.0 & 0.5 & 0.0 & 27 \\
Total of above & 0.8 & 0.6 & 0.5 & 0.3 & 0.0 & 636 \\
\hline
\end{tabular}

Sources: World Bank and OECD, Labour Force Statistics. 


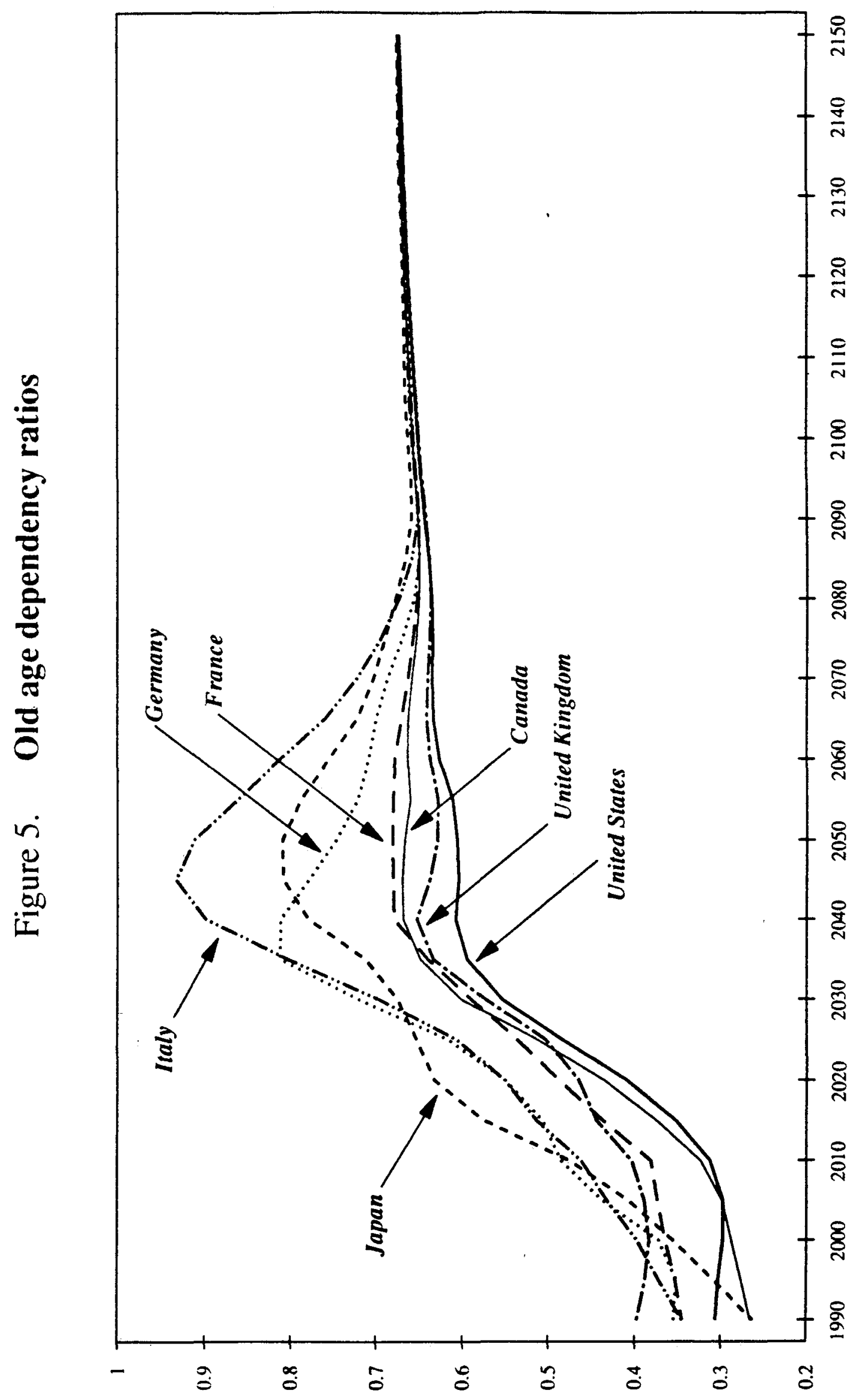


The projected proportion of people of 60 years of age and over who actually receive a retirement pension (the eligibility ratio), varies between 0.69 in Germany (where dependent spouses are not automatically eligible to an old-age pension) and virtually unity in Japan, France and Italy (Table 4, first column) (18). The ratios used are average for all retired age groups even though there are differences across age brackets. Generally speaking, the eligibility ratio for the age bracket 60 to 64 is lower than for the subsequent age brackets, as people in this bracket may not have yet attained the minimum pensionable age (which may be higher than 60) or may have opted for deferred retirement.

The employment ratio per age bracket has been held constant at its 1990 level. However, the average employment ratio for the working-age population as a whole may move away somewhat from its initial level -- as a result of progressive ageing and the associated change in weights (Table 4, third column).

The ratio of the real pension rate per beneficiary and real output per worker (the transfer ratio) is projected to remain constant for each age-grouping. Real pension rates of beneficiaries when entering retirement are assumed to move in line with real output per worker reflects real earnings growth. Real output per worker is assumed to grow by 2 per cent per annum, except in the United States where it is assumed to grow by 1 per cent per annum. Such growth is in line with historical developments (19). Pension benefits are then assumed to be held constant over the period of retirement in real terms. This implies that the transfer ratio moves solely as a result of the changing age structure of the retired population. An ageing population will produce a gradual decline in the overall transfer ratio, reflecting an increase in the proportion of the very old -- with lower pension rates than younger cohorts. This is, indeed, the general trend, in the long-run culminating in transfer ratios below the ones recorded in the 1980 s except for the United Kingdom and Canada, where pension rates undergo a structural upgrading (Table 4, second column).

Two other crucial economic variables have to be projected: real GDP, to convert the expenditure ratios into a flow of absolute amounts, and the discount rate to convert this flow into a present value. Real GDP growth reflects the assumed rate of growth of the working population, movements in the employment ratio and the assumed rate of growth of output per worker (discussed above). As concerns the discount rate, the two paths discussed earlier (Part III) have been used again.

\section{Results}

The expenditure ratio is expected to grow sharply between 1990 and 2040 , the year in which the old-age dependency ratio reaches its peak, on the basis of the above assumptions. Italy shows the sharpest increase in the expenditure ratio: from 11 per cent of GDP to almost 23 per cent of GDP in 2040 (Figure 6). In France, the ratio is calculated to increase from 9 per cent in 1990 to 15 per cent at the peak. The recently announced changes in accrual rights will reduce this figure. In the other countries the ratio increases from 4 to 6 per cent in 1990 to 10 to 13 per cent in 2040 . 


\begin{tabular}{lccc}
\hline & $\begin{array}{c}\text { Eligibility } \\
\text { ratio }\end{array}$ & $\begin{array}{c}\text { Transfer } \\
\text { ratio (1) }\end{array}$ & $\begin{array}{c}\text { Employment } \\
\text { ratio (2) }\end{array}$ \\
\cline { 2 - 4 } United States & 0.75 & 0.176 & 0.85 \\
Japan & 1.02 & 0.135 & 0.90 \\
Germany & 0.69 & 0.168 & 0.76 \\
France & 1.00 & 0.156 & 0.73 \\
Italy & 0.98 & 0.163 & 0.75 \\
United Kingdom & 0.89 & 0.161 & 0.87 \\
$\begin{array}{l}\text { Canada } \\
\text { Average of above } \\
\text { countries }\end{array}$ & 0.84 & 0.142 & 0.82 \\
\hline
\end{tabular}

Note: The eligibility ratio is defined as the ratio between the number of old-age retirement beneficiaries to the number of people of 60 years and over.

The transfer ratio is defined as the ratio between the average old-age retirement benefit and GDP per worker.

The employment ratio is defined as the ratio between the number of people employed and the population of working age (here between 20 and 60 ).

1. Weighted average for age brackets 60 to 64,65 to 69,70 to 74 and over 75 , in the stationary state.

2. Weighted average for age brackets 20 to 24,25 to 29,30 to 34 , 35 to 39,40 to 49,50 to 54 and 55 to 60 , in the stationary state. 


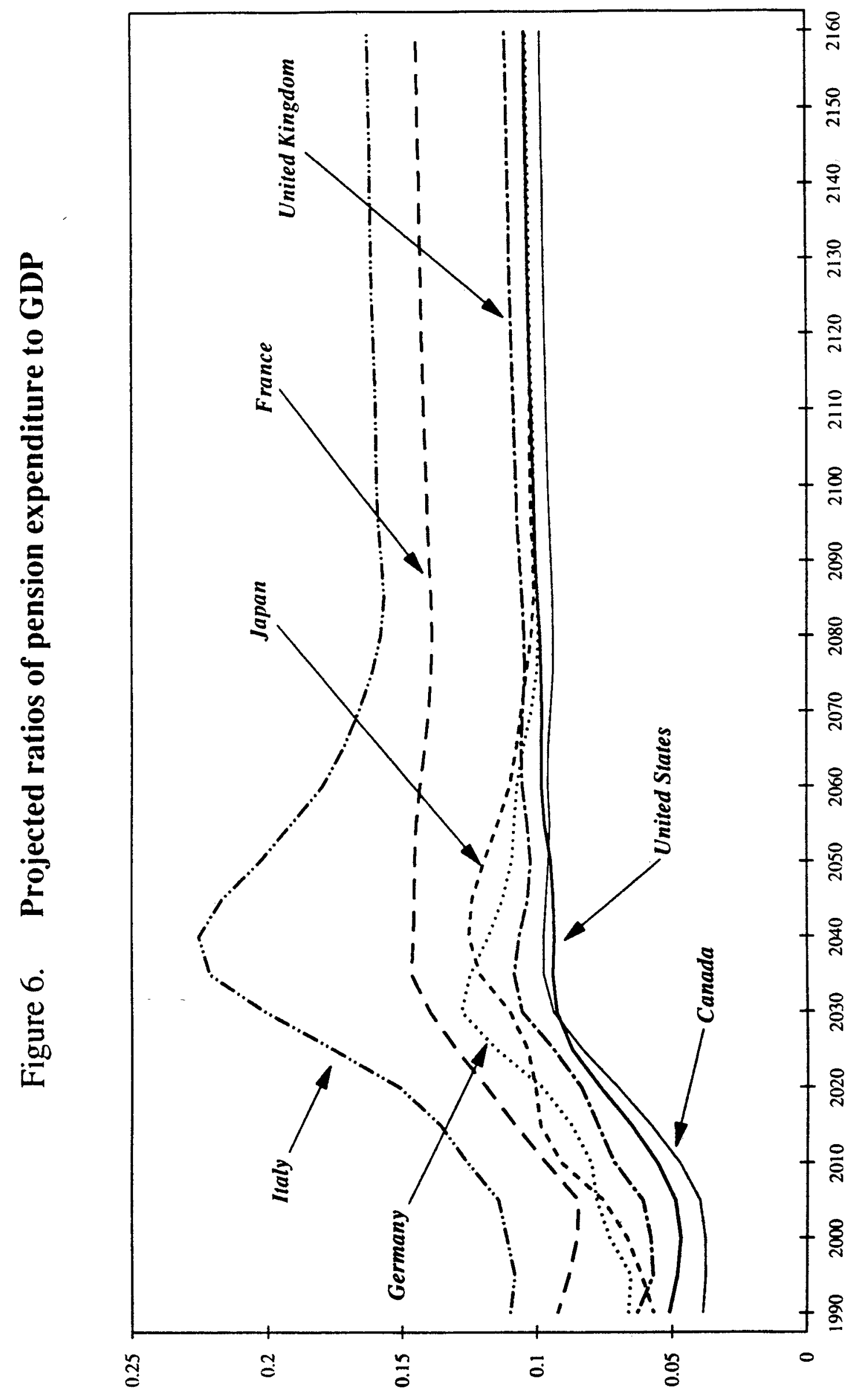


On average, future pension rights are projected to generate liabilities of around three-and-a-half times 1990 GDP, almost twice the level of liabilities associated with existing entitlements (Table 5). Italy and France are estimated to face particularly large total pension liabilities of around seven times their 1990 GDP. For Italy, this mainly reflects the demographic outlook; in France it results from the assumptions of a high eligibility ratio for all old-age brackets including the youngest one, a relatively generous transfer ratio and a relatively low employment ratio. The announced increase of the pensionable age by five years in Italy is estimated to reduce the implicit liability by an amount roughly equal to its 1990 GDP, on the assumption that by 2010 no people under 65 are retired. In the United States total liabilities are estimated to be only three times 1990 GDP. In the other countries, total pension liabilities are estimated at around five times 1990 GDP. The recent reforms in the French pension system have not been taken into account.

\section{An estimate of future pension contributions and net liabilities}

\section{Assumptions}

The evolution of future contributions has been calculated on the assumption that contributions relative to GDP remain constant over the projection period. However, it is not always clear what the initial level of contributions has been. In many countries, identified contributions to government pension schemes cover only part of the expenditure, the remainder being financed from other sources, such as interest earnings, subsidies and borrowing. In order to estimate contribution ratios, two approaches have been applied. For countries that employ PAYG financing, the relevant contribution ratio in 1990 is assumed to have been equal to the pension-expenditure ratio in that year (Table 6). In the United States and Japan, where there are funded schemes, actual contributions have been used. Contributions exceed pension expenditure in these two countries.

\section{Results}

Future contributions are projected, on average, to be equal to three-and-a-half times the value of GDP in 1990 with markedly larger figures for France and Italy due to high contribution rates (Table 7). It is noticeable for the group of countries as a whole that the present value of future contributions is equal to the present value of future pension rights. (A detailed discussion of the extent to which these pension schemes transfer wealth between generations is to be found in Annex 2).

Under the assumption presented above, all systems have large net liabilities. Unfunded liabilities run from less than half 1990 GDP for the United States, reflecting a combination of the favourable demographic outlook and substantial existing funds, to over twice 1990 GDP in France, Italy and Canada (Table 7). The net liabilities, on average, are equal to the present value of currently acquired rights and pensions already in payment.

An increase in the projected discount rate by $11 / 2$ percentage points reduces the deficits substantially (Table 8). Net liabilities would still be 


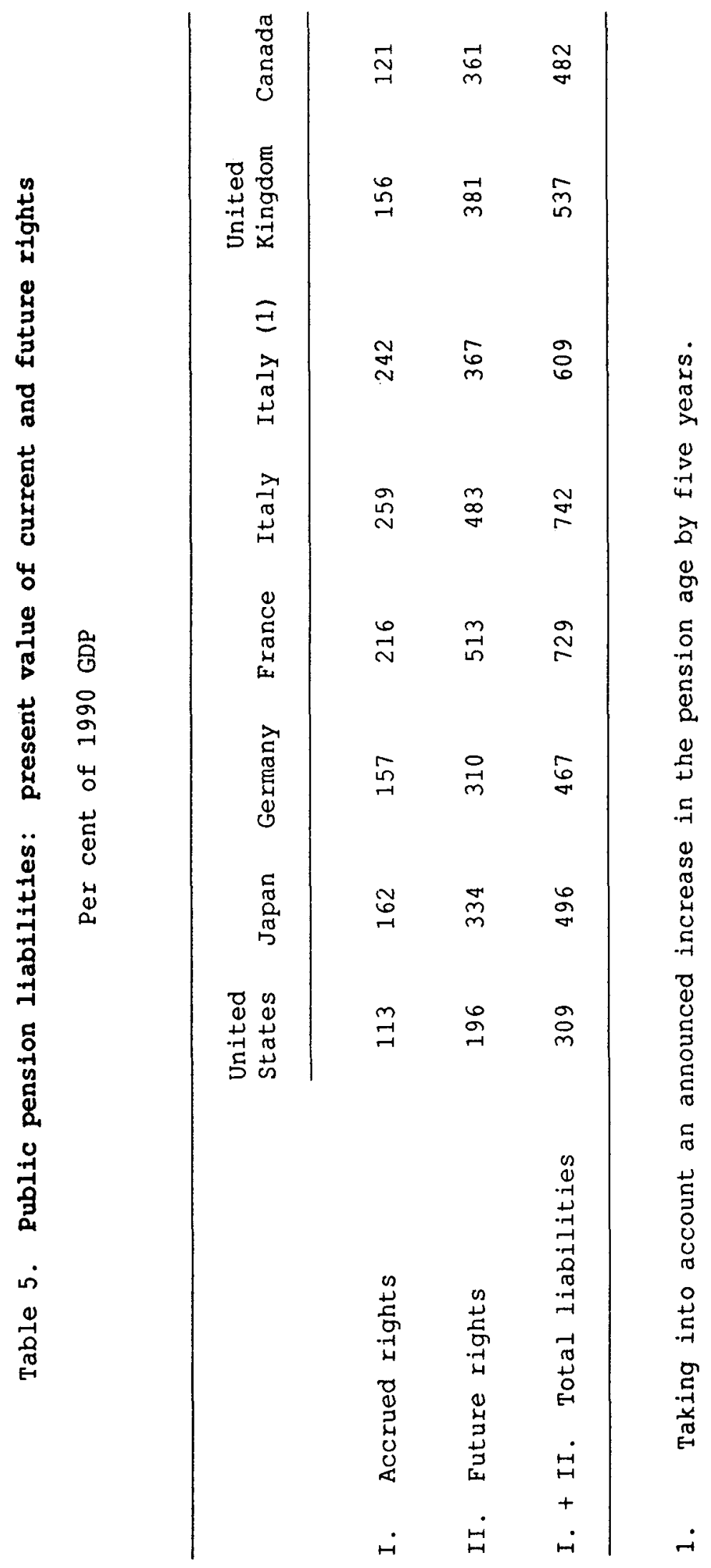




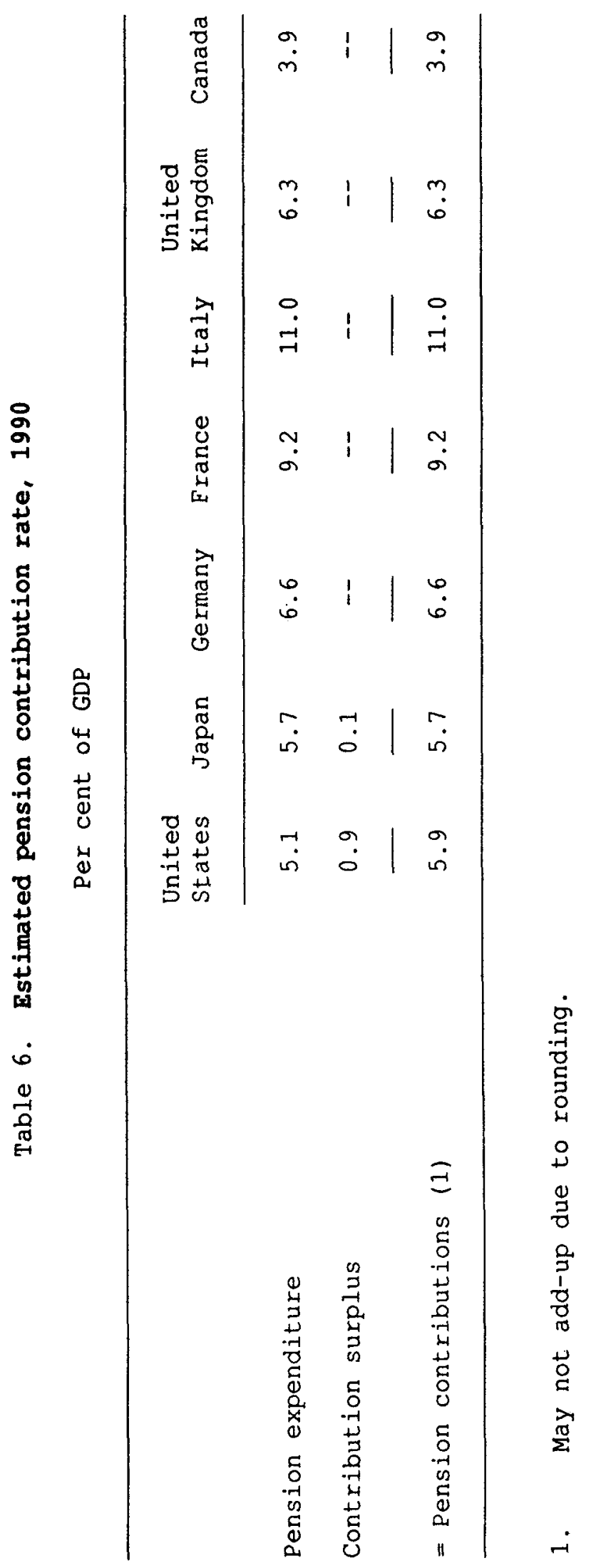




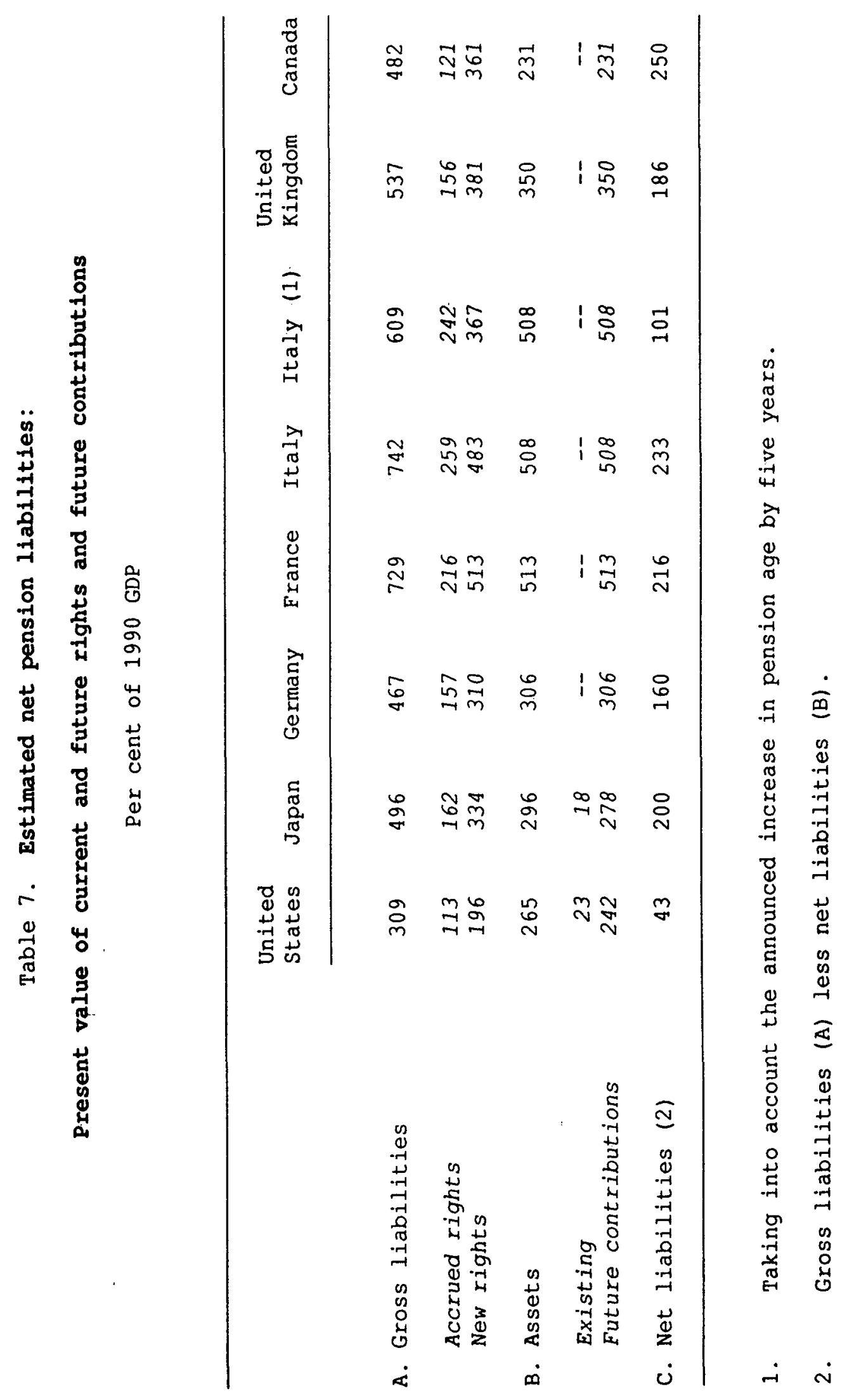




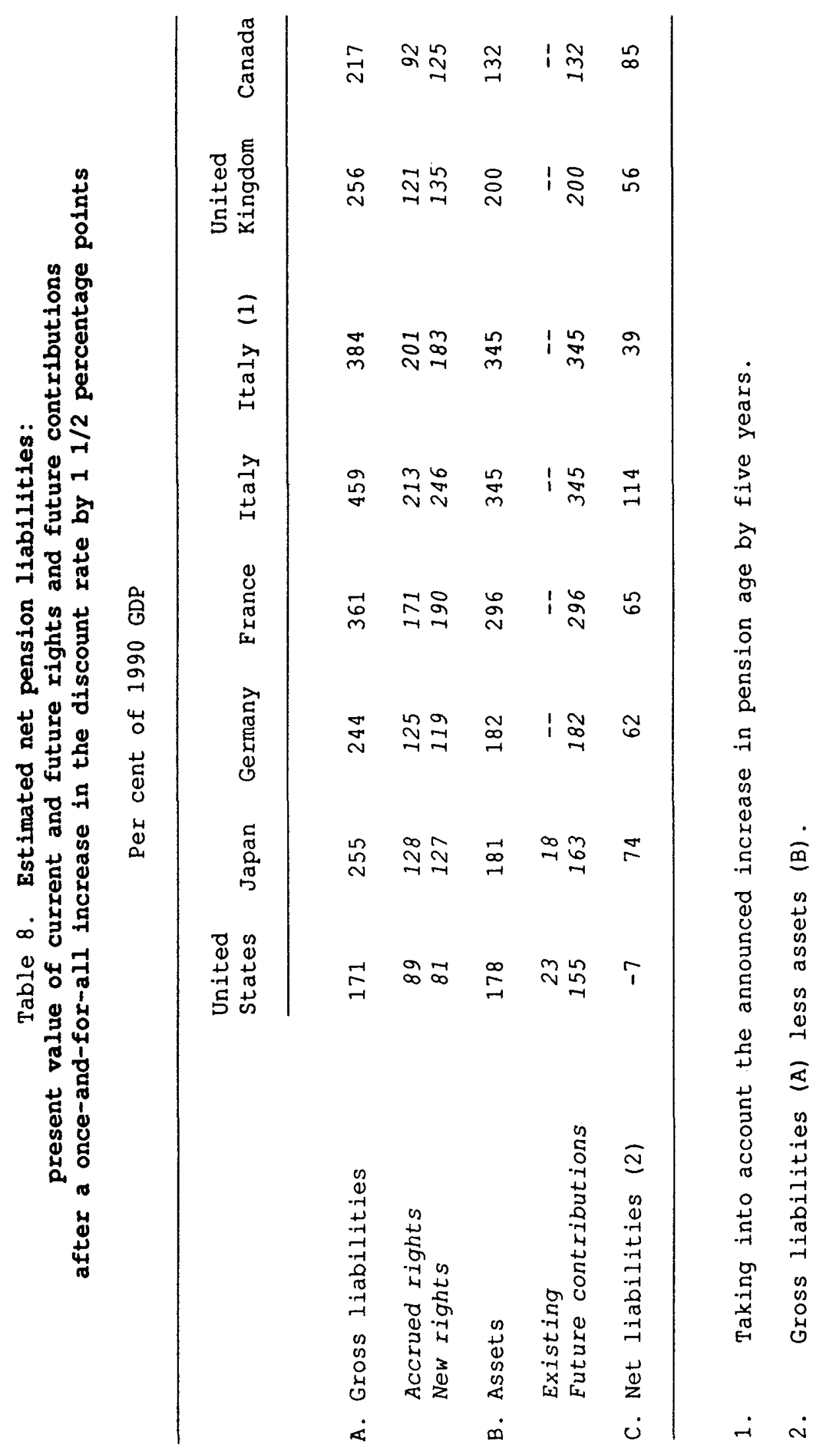


as large or larger than government debt, except in the United States where there would be a slight surplus.

The net pension-related indebtedness of the government mainly concerns the older cohorts of the present workforce and those now retired, for whom no or too small financial assets have been accumulated in the past (see Annex 2). The reason for this, obviously, is that their contributions have been used to finance current pension expenditure, as most schemes have operated on a Pay-As-You-Go basis. These features result in a "dead-weight" indebtedness, which, given its disproportionate size, can only be financed by progressively charging future generations. A more complete analysis would also take into account the contributions made by pensioners and the current work-force.

\section{Financing Pension Liabilities}

This part explores four financing scenarios to prevent gaps arising between public pension expenditure and contributions:

i) continuing Pay-As-You-Go financing, ensuring that contributions in any year increase as necessary to match current pension expenditure;

ii) allowing contributions in the short and medium term to exceed pension expenditure in order to create a fund which could be used to help financing future pension entitlements (quasi-funding);

iii) lessening the extent to which the periodical revaluation of past earnings appearing in the pension formula is linked to overall earning trends; or

iv) increasing the pensionable age.

A further option which involves a gradual increase in the contribution rate, rather than the step increase used here, has been analysed in an earlier OECD study (20). A more detailed analysis of the material presented below can be found in Annex 3.

\section{The required changes according to four scenarios}

In summary, these scenarios suggest that, in most countries, either substantial increases in the contribution rates will be required, or generosity of the systems will have to be scaled back to a large degree (Table 9). If Pay-As-You-Go financing were to be continued (or be reintroduced), contribution ratios would have to be gradually increased by $4-6$ percentage points over the next three decades or so, and by almost 12 percentage points in Italy. In the case of quasi-funding, a once-and-for-all increase in the contribution ratio in the range of 3-5 percentage points would be required, except in the United States, where an increase by 1 percentage point would be sufficient. If increases in the contribution ratio were to be ruled out, the assessed earnings on which pensions are based would have to be uprated at less than 50 per cent of the rate of growth of average real earnings instead of moving in line with average earnings as assumed in the baseline. The uprating would have be be as 


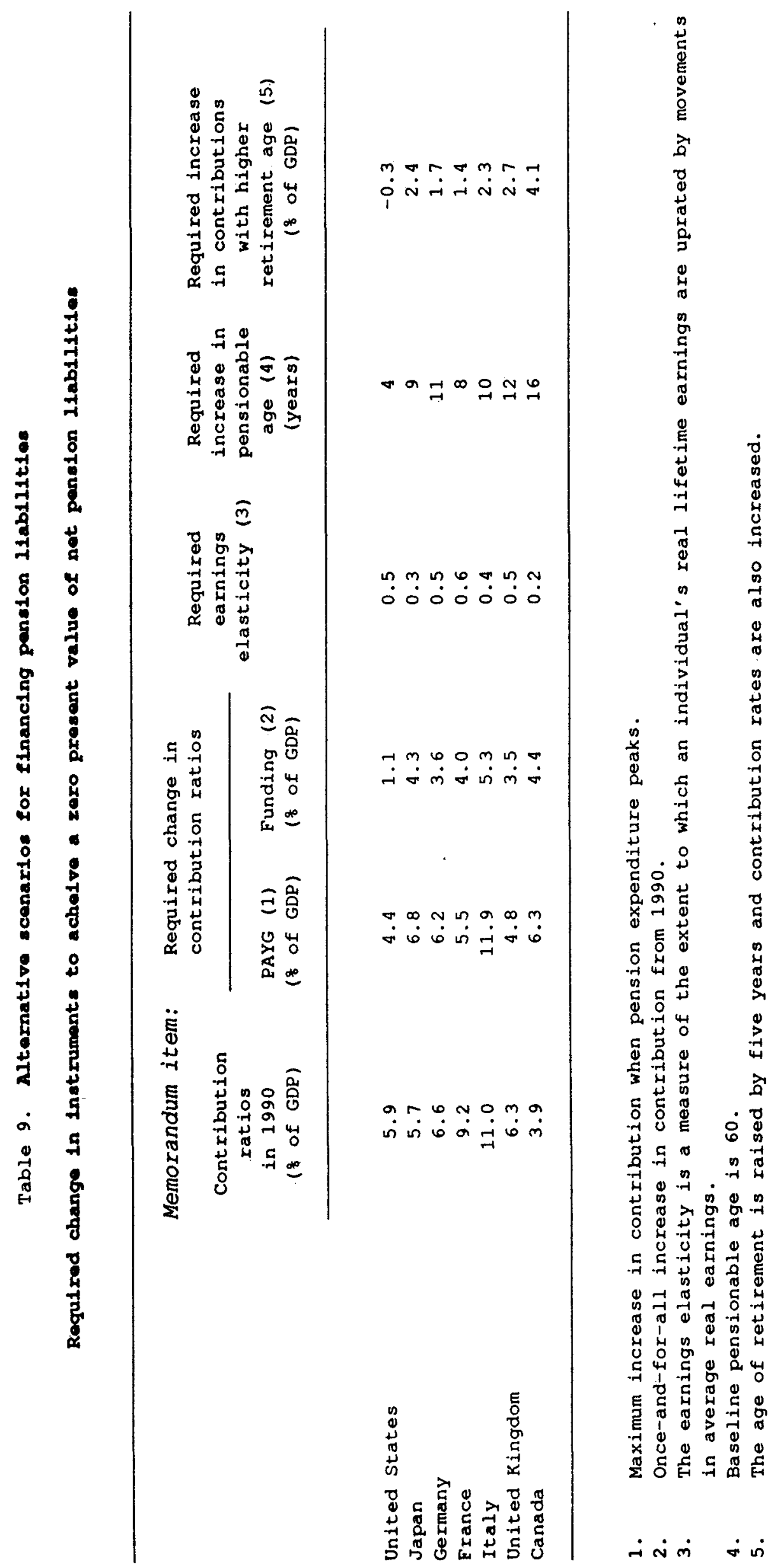


low as 20 per cent of real average earnings growth in Canada. Alternatively, the pensionable age would have to increase by around ten years in most countries, but by only four years in the United states and by 16 years in Canada.

The eventual choice of policies to meet this problem will depend on the specific features of each public pension system together with demographic outlooks. With substantial assets already held by the United States' public pension schemes, that country could continue relying on a funded regime in the future with only a small increase in the contribution rates. It could even be smaller than suggested by these calculations, as the government has announced an increase in the pensionable age of two years. The scenarios for Canada illustrate that as contribution rates are at relatively low levels, other policies aimed at eliminating deficits generate extreme results. Japan already plans to increase contribution rates in the future. Germany may well have to strike a more complex balance between the various options in developing a suitable policy mix. With contribution rates already relatively high in France and Italy, relatively more attention may have to be given to increasing the pensionable age (an action recently taken in Italy), lowering benefits, or lower accrual rates (as proposed in France).

\section{The effects on the inter-generational distribution of wealth}

The eventual choice of financing method may also be influenced by differences in the transfers of wealth between present generations (today's workforce and the retired) and future generations (present and unborn children) implied by different financing schemes (Table 10). Pay-As-You-Go (PAYG) financing would necessitate the largest transfer of wealth from future to present generations and retired, of the order of magnitude of one to two times 1990 GDP (more than twice 1990 GDP in Italy), reflecting significant increases in contribution rates to be borne by future generations. Reducing the pass-through of real earnings growth in real pension rates also appears to have particularly large effects on future generations, even though the transfers involved are somewhat lower than those required under a PAYG scenario. As discussed in Annex 3, this scenario is probably not feasible, as real pension rates would persistently decline relative to overall real earnings.

The introduction of quasi-funding, at the other extreme, implies a "front-loading" of future contributions, increasing the cost to present generations and relieving future ones relative to a PAYG scenario. Even in this scenario, however, future generations would still have to make a transfer of wealth to present ones in the range of half to one-and-a-half times 1990 GDP. Increasing the pensionable age would lead to a more balanced outcome from the point of view of inter-generational equity, with transfers of wealth somewhat below what would be required under a funded regime. It should be noted, though, that it has been assumed that contributions are held constant as the retirement age is raised, which generates some funding of the pension scheme. Given these results, a combination of a once-and-for-all increase in the contribution ratio and a five year increase in the retirement age would also be relatively balanced from the point of view of inter-generational equity. 


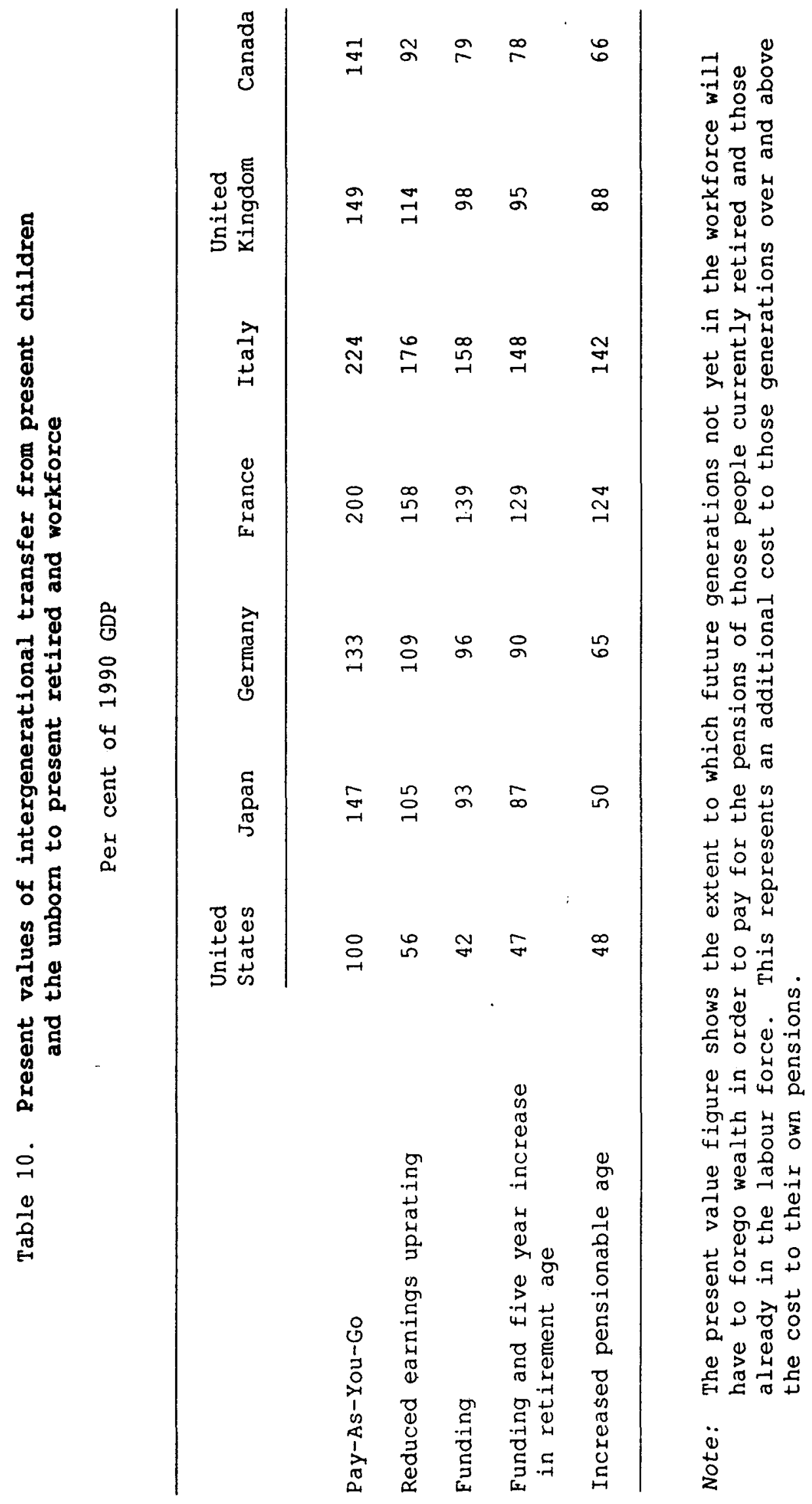




\section{Conclusions}

Ageing populations will put increasing strain on public finances as expenditure on pensions grows. The paper illustrates that the present value of future liabilities exceeds the present value of future income based on constant contribution rates by a margin that, on average, exceeds 130 per cent of 1990 GDP. This liability can be split into two parts:

i) commitments relating to pensions either already in payment or arising from rights that have already accrued. Typically, this accounts for virtually all of the total net liability; and

ii) commitments relating to future benefits (i.e. those which have not yet accrued) and future contributions. Typically, the estimated present values of these two factors are broadly in balance.

These estimates of liabilities underline the point that pension schemes will put increasing pressure on public finances implying the need to increase contribution rates or reduce pension entitlements over time. The inclusion of the capitalised net pension liabilities in a government balance-sheet would give an early warning of the extent to which such problems might arise. Including the accrual of pension liabilities in a wider definition of debt would also change the assessment of relative debt positions of different countries.

The extent of the net pension liability depends crucially on the discount rate used to value income and expenditure flows in calculating present values. In the results reported in the previous paragraph, a discount rate of 4 per cent, falling to 3 per cent in the long term, was used. If a discount rate $11 / 2$ percentage points higher had been used, the net liability, on average, would fall from 130 per cent to 50 per cent of 1990 GDP -- which is still high enough to remain a matter of concern. Amongst the seven major countries considered, net pension liabilities are only estimated to be less than the net debt of governments in two cases (the United States and Italy).

A number of policy options for the elimination of the pension liability (pay-as-you-go financing, a reserve fund, raising the retirement age and lowering pension benefits) were investigated in the paper. Relying on pay-as-you-go financing would result in a peak contribution rate nearly double current levels in most countries. A once-and-for-all increase in contribution rates with the surplus contributions being placed in a reserve fund would require a 50 per cent increase in current contribution rates, with a larger increase in those countries with pension schemes that are still maturing and a smaller increase in the united States. A substantial increase in the retirement age would be required in all countries with a particularly marked increase in Canada where current contribution rates are low. Raising the retirement age can have a substantial impact on the liabilities of a state pension scheme, as is shown by the halving of the Italian pension liability following the increase of five years in the retirement age.

These various possible policies would generate markedly different distributions between generations of the financing costs of eliminating the net pension liability. Future generations would make the largest transfer in the 
case of a pay-as-you-go scheme, while the transfer from future generations is the least when the retirement age is increased. An immediate increase in contributions also results in a relatively low transfer from future generations.

\section{Notes}

1. The authors are indebted to Peter Scherer and Elizabeth Duskin of the Directorate for Education, Employment, Labour and Social Affairs for several stimulating discussions, to Bryn Davies (external consultant) for his advice on actuarial issues and to Mike Feiner and Constantino Lluch for their comments on an earlier draft.

2. See for the United States: Office of Management and Budget, "Generational Accounts presentation", Budget of the USA, FY 1993, August 1992, Part Three, pp. 7-13; and for Italy: D. Franco, J. Gokhale, L. Guiso, L.J. Kotlikoff and N. Sartor, Generational Accounting: The Case of Italy, Banca d'Italia, Temi di discussione del Servizio studi, No. 171, 1992; see for a discussion of generational accounting A.J. Auerbach, J. Gokhale and L.J. Kotlikoff, "Generational Accounting: a meaningful alternative to deficit accounting" in: D. Bradford (ed.), Tax Policy and the EConomy, NBER, MIT Press, 1991, pp. 55-110.

3. Throughout this working paper data for Germany cover western Germany only. The impact of the ageing of the population on four economies (United States, Germany, Japan and Sweden) was analysed from a somewhat different angle in an earlier OECD study, see Alan J. Auerbach, L.J. Kotlikoff, R.P. Hagemann and G. Nicoletti (1989), "The economic dynamics of an ageing population: the case of four OECD countries", OECD EConomic Studies No. 12 (Spring), focusing on the welfare gains to different generations stemming from different pension financing policies rather than on the size of the "off-budget" government liability.

4. This approach is based on earlier work reported in O. Blanchard, J-C. Chouraqui, R.P. Hagemann and N. Sartor, "The sustainability of fiscal policy: new answers to an old question", OECD EConomic Studies, No. 15, 1990, pp. 7-36.

5. Provided that the rate of return exceeds the rate of growth of earnings and the associated rates of growth of contributions and benefits, the so-called Aaron rule.

6. For a discussion of long-term trends in pension expenditure, see OECD, Reforming Public Pensions, Paris, 1988.

7. In 1993, the average real long-term interest rate in the main seven economies is 4.2 per cent. 
8. Long-term rates in the United States and the United Kingdom averaged 5.2 per cent in this period. Lower real rates between 1930 and 1980 could perhaps be attributed to an over-valuation of non-risk bearing capital, in part reflecting a tendency towards risk aversion in the wake of the fall in share prices in 1929, see J.J. Siegel, "The real rate of interest from 1800-1990; A study of the US and the UK", Journal of Monetary EConomics, Vol. 29, 1992, pp. 227-252.

9. Siegel, op. cit.

10. Moreover, the real rates of return of private pension funds have significantly exceeded real rates of interest in the 1970 s and 1980 s, see B.D. Davies, Pension Scheme Surpluses, paper presented to the Staple Inn Actuarially Society, 22 October 1991 (mimeo.), and E.P. Davis, "The development of pension funds in the major industrial countries", in $\mathrm{J}$. Mortensen (ed.) The Future of Pensions in the European Community, Brassey's, Brussels, 1992, pp. 107-131.

11. Siegel, op. cit.

12. J. Hills, Does Britain have a 'Welfare Generation'? An empirical analysis of intergenerational equity, WSP Discussion Paper/76, London School of Economics, August 1992.

13. Moreover, the real rate of return of public pension funds may overstate the relevant discount rate, at least from the point of view of future pensioners. A reason for this is that the supply of public pension facilities is effectively rationed by the government given that there is no market for marginal annuities. Hence, pension rights that do accrue within the existing system have a higher valuation (and a lower implicit discount rate) than a hypothetical marginal annuity. See for this argument, T.W. Mirer, "Life-cycle valuations of social security and pension wealth", Journal of Public Economics, Vol. 48, 1992, pp. $377-384$.

14. More specifically, the following relationship holds by definition:

Expend. Ratio $=01 d$-age Dep. Ratio $x \frac{\text { Eligibility Ratio } x \text { Transfer Ratio }}{\text { Employment Ratio }}$ where:

$\begin{aligned} \text { Expenditure ratio } & =\text { Pension expenditure as a ratio to GDP; } \\ \text { Old-age Dependency ratio }= & \text { Population at pension age divided by the } \\ & \text { population at working age; } \\ = & \text { Number of pension beneficiaries divided by } \\ & \text { the population at pension age; } \\ = & \begin{array}{l}\text { Pension per beneficiary divided by GDP per } \\ \text { wransfer ratio } \\ =\end{array} \\ \text { Employment ratio } & \begin{array}{l}\text { Employment divided by the population at } \\ \text { working age. }\end{array}\end{aligned}$

15. World Bank Development Report 1992, World Bank, Washington. 
16. This projection is based on assumptions regarding fertility, mortality, and international migration, which ensures that the population eventually becomes stationary. In such a situation, the birth rate is constant and equal to the death rate, the age structure is constant, and the growth rate of the population is zero. Mortality is projected by extrapolating recent trends in male and female life expectancy and infant mortality. Countries are assumed to have constant fertility rates until 1995-2000 and then to move up to the replacement level by 2030 .

17. Recent projections by the United States Census Bureau suggest that, due to revised expectations on net immigration, the U.S. population will grow by 50 per cent between 1990 and 2050, rather than by 30 per cent as implied by the World Bank projections used here.

18. Wherever the same people receive a pension from more than one source, they have been counted only once, except in Japan.

19. The rate of growth of real GDP per worker in the period 1980-90 has been 0.9 per cent in the United States and 2 per cent on average in the other major countries, with a standard deviation of 0.5 percentage points. Very long time-series show that labour productivity growth rates in the last century or so have been of the same order of magnitude, see A. Maddison, "Growth and slowdown in advanced capitalist economies: techniques of quantitative assessment", Journal of Economic Literature (June), pp. 649-98, quoted in A.S. Englander and A. Mittelstädt (1988), "Total factor productivity: macroeconomic and structural aspects of the slowdown", OECD EConomic Studies, No. 10 (Spring), pp. 7-56; in particular Table 3 on page 19.

20. Robert P. Hagemann and G. Nicoletti (1989), "Population ageing: economic effects and some policy implications for financing public pensions", OECD ECOnomiC Studies No. 12 (Spring). 
Annex 1

Public Pension Systems in the Seven Major Economies

This annex provides some country-by-country background information with respect to the scope, the pension formulas and the financing of public pension systems, against which the standard assumptions underlying the calculations in the main paper can be judged. Table 1.1 provides a schematic overview of the main schemes in the countries under consideration and Table 1.2 indicates the level of expenditure per type of scheme and the number of beneficiaries. More detailed data for each of the countries are presented in Tables 1.4 to 1.10 at the end of this annex.

\section{United States}

Virtually all civilian employed, including self-employed, are covered by the earnings-related old-Age Survivors and Disability Insurance (OASDI). In addition, a means-tested minimum allowance may be granted. Retired public employees, both at the Federal and the State and Local levels, are entitled to a supplement on top of their basic pension. For veterans and railroad employees, separate pension schemes exist.

Under the OASDI scheme, pension benefits are based on career earnings, with a maximum replacement rate of around 40 per cent. The accrual rate varies inversely with earnings. As concerns the retirement age, in the $1980 \mathrm{~s}$ two measures were introduced to encourage older workers voluntarily to remain longer in employment. First, additional credits for delayed retirement after the standard retirement age of 65, were increased. Second, means tests after 65 were eased. Moreover, the minimum retirement age for unreduced retirement will be gradually increased to 67 .

The OASDI trust fund held $\$ 225$ billion of assets at the end of 1990, of which $\$ 204$ billion for the financing of future old-age retirement pensions (Table 1.3). According to official projections, the fund will increase from the present 4 per cent of GDP to 24 per cent in 2018. After that year the scheme will be accumulating deficits and the assets will be gradually run down to zero by 2041 (1). Apart from OASDI, several categorial pension funds held assets worth around $\$ 1080$ billion at the end of 1990 , bringing the total at around 23 per cent of GDP.

\section{Japan}

The general scheme, the Kokumin-Nenkin scheme (KN), provides a basic flat-rate pension to all residents including self-employed and jobless persons. It was created in 1961 and extended to dependent spouses in 1984. Five other 


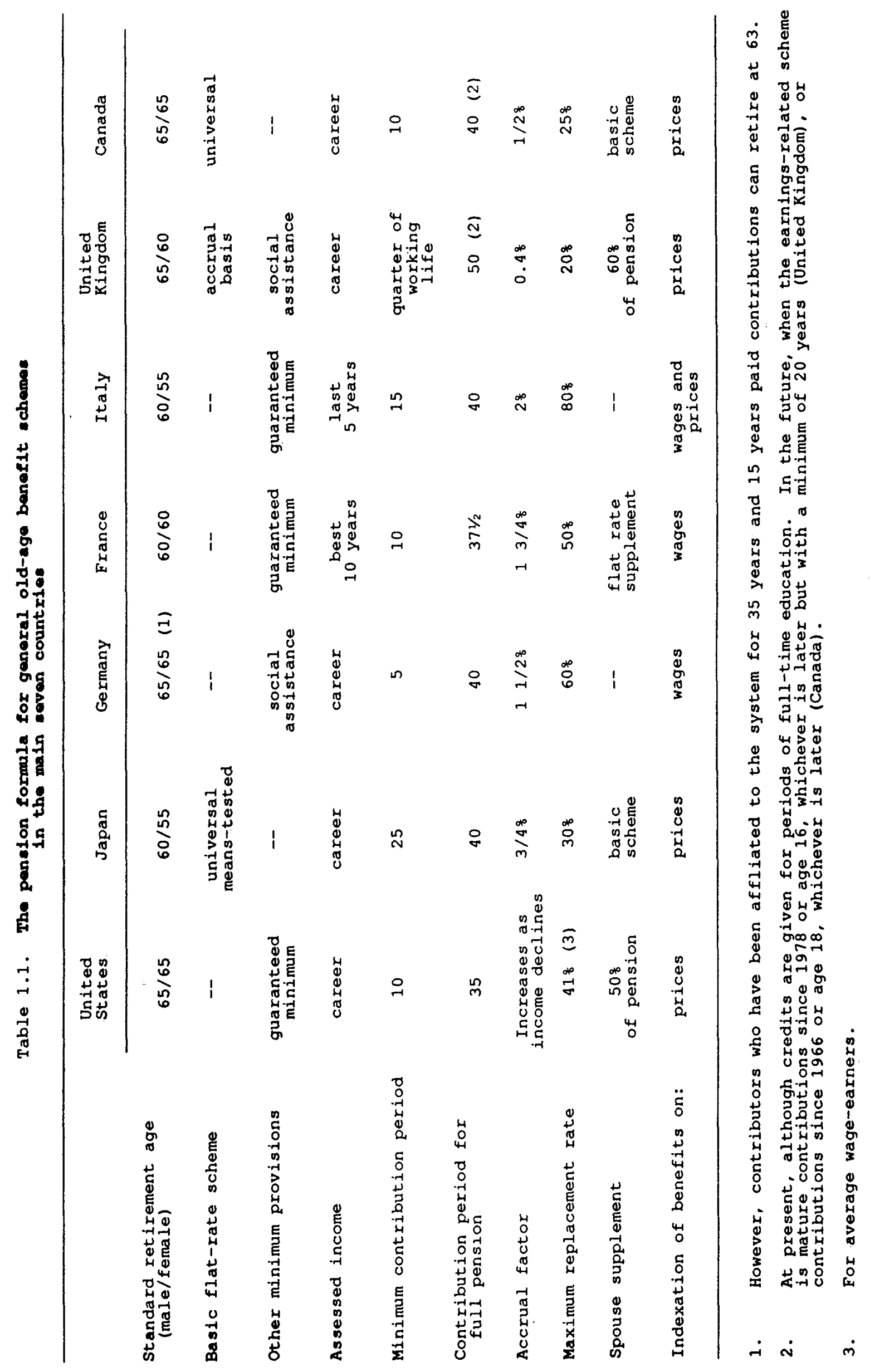




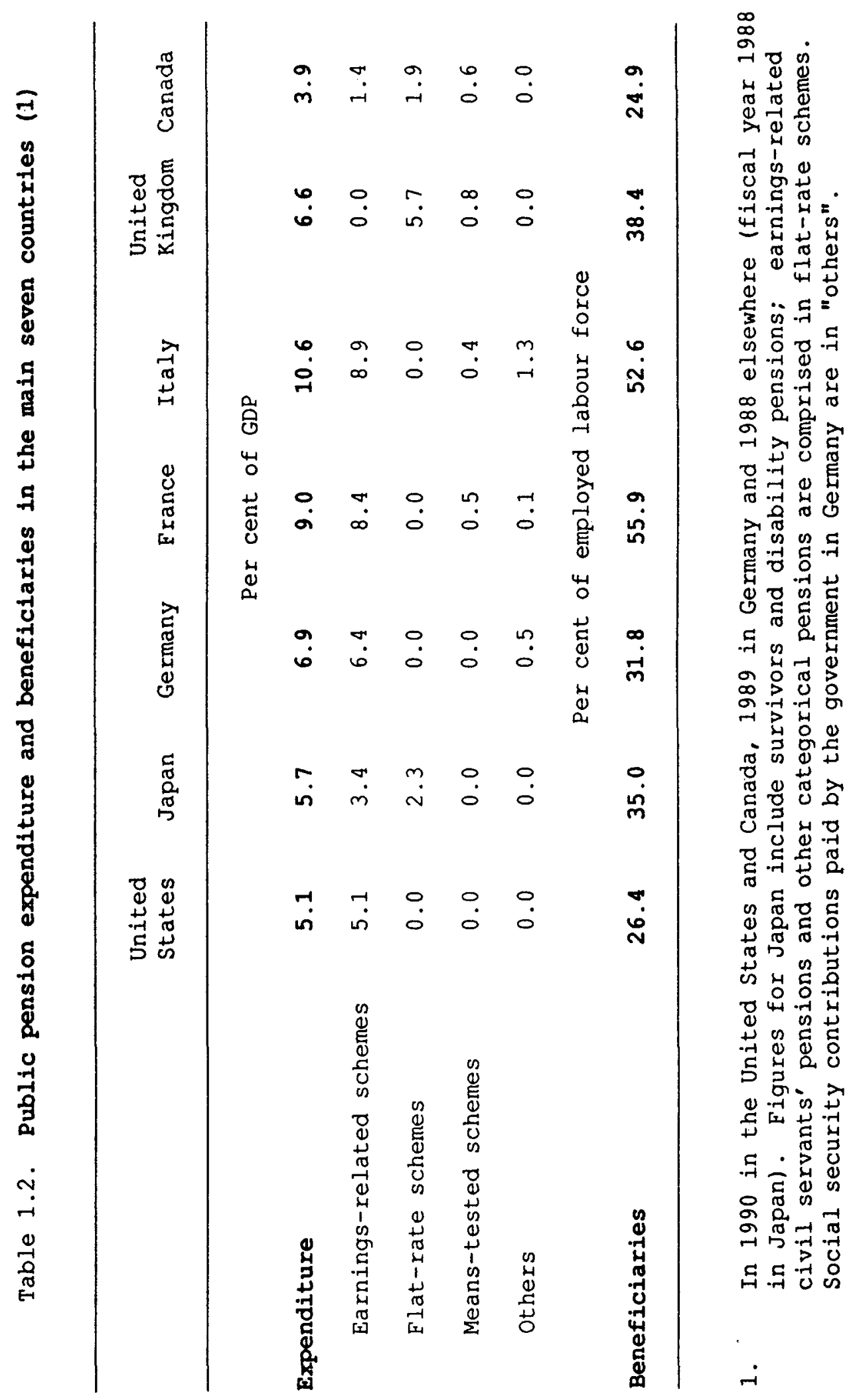


Table 1.3. The cumulation of asset in funded schemes in $I 990$

\begin{tabular}{|c|c|c|c|c|c|}
\hline \multirow[b]{3}{*}{ United states } & \multirow{2}{*}{$\begin{array}{l}\text { Assets at the } \\
\text { beginning } \\
\text { of the year }\end{array}$} & \multicolumn{3}{|c|}{ Change in assets } & \multirow{2}{*}{$\begin{array}{l}\text { Assecs at } \\
\text { the end } \\
\text { of the year }\end{array}$} \\
\hline & & Total & $\begin{array}{l}\text { Interest } \\
\text { earnings }\end{array}$ & $\begin{array}{l}\text { Primary } \\
\text { surplus }\end{array}$ & \\
\hline & \multicolumn{5}{|c|}{ billions of U.S. dollars } \\
\hline Total & 1191.5 & 89.0 & 41.5 & 47.5 & 1280.5 \\
\hline $\begin{array}{l}\text { as a percentage of GDP } \\
\text { of which: }\end{array}$ & 21.6 & 1.6 & 0.8 & 0.9 & 23.2 \\
\hline $\begin{array}{l}\text { Old age insurance (OASDI) } \\
\text { Railroad retirement } \\
\text { Veterans }\end{array}$ & $\begin{array}{r}148.6 \\
8.5 \\
53.6\end{array}$ & $\begin{array}{r}55.2 \\
0.7 \\
11.3\end{array}$ & $\begin{array}{r}14.2 \\
0.7 \\
4.8\end{array}$ & $\begin{array}{r}41.0 \\
0.0 \\
6.5\end{array}$ & $\begin{array}{r}203.8 \\
9.2 \\
64.9\end{array}$ \\
\hline $\begin{array}{l}\text { Public employee retirement } \\
\text { of which: }\end{array}$ & 980.8 & 21.8 & $2 i .8$ & 0.0 & 1002.6 \\
\hline $\begin{array}{l}\text { Federal } \\
\text { State and local }\end{array}$ & $\begin{array}{l}229.1 \\
734.9\end{array}$ & $\begin{array}{l}22.0 \\
16.6\end{array}$ & $\begin{array}{l}19.3 \\
59.9\end{array}$ & $\begin{array}{r}2.7 \\
-43.3\end{array}$ & $\begin{array}{l}251.1 \\
751.5\end{array}$ \\
\hline Japan & \multicolumn{5}{|c|}{ trillions of yen } \\
\hline Total (KNH scheme) & 71.1 & 5.5 & 5.0 & 0.5 & 76.6 \\
\hline as a percentage of GDP & 16.7 & 1.3 & 1.2 & 0.1 & 18.0 \\
\hline
\end{tabular}

Sources: Budget of the United States Government, fiscal years 1992 and 1993. N. Takayama (1992). The Greying of Japan: an Economic Perspective on Public Pensions, Kinouniya Company Itd./Oxford University Press, and own estimates. 
schemes, which already existed before 1961, provide supplementary earnings-related pensions. The main programme in this area is the Kosei-Nenkin-Hoken (KNH) scheme, which covers all private employees, and which also administers the $\mathrm{KN}$ pensions for its members. Special supplementary schemes exist for civil servants of the central government, local government employees, private school teachers and employees and employees in the agricultural sector.

Japan is one of the three countries to combine an earnings-related system with a basic flat-rate scheme (the United Kingdom and Canada are the other two) (2). The basic scheme ( $\mathrm{KN}$, see above) covers all residents of age 20 to 60 and was first put into effect on 2 April 1961. The full pension is payable after 40 years of contributions, a requirement which can only be met by those born 20 years or less before the law became effective, thus after 2 April 1941. But also those born between 2 April 1926 and 2 April 1941 with at least 25 years of coverage are entitled to the full pension, as a transitional arrangement. The benefit is adjusted every year for CPI changes with a one-year lag. The pension may be claimed at any age between 60 and 70 subject to an actuarial reduction before 65 and an increase after 65 . The earnings-related $\mathrm{KNH}$ scheme covering private sector workers, is on an accrual basis, with an accrual rate of 0.75 per cent per year, or 30 per cent over 40 years (of the career average monthly earnings). For those born before 1 April 1946 there is a provisional arrangement, with an accrual rate of 1 per cent for those born before 1927 and varying between 0.986 per cent and 0.75 per cent depending on the date of birth for those born later. The career average monthly earnings are adjusted for general earnings increases every five years, and once retired, the benefit is indexed on the CPI. The full pension is payable from age 60 and a supplement is granted between 60 and 65 to make up for actuarial reductions in the $\mathrm{KN}$ system. The typical beneficiary in 1991 receives a benefit of 68 per cent of his earnings excluding bonuses on a gross basis, or 80 per cent on a net basis. Firms with more than 500 workers can contract out the earnings-related portion of $\mathrm{KNH}$ pensions by setting up a private fund.

The KNH scheme hold assets of around 18 per cent of GDP (Table 1.3). All other schemes are financed on a Pay-As-You-Go basis. However, even under the KNH system present contribution rates match current benefits, while the interest earnings are entirely used to accumulate further assets. Hence, the KNH scheme at present effectively operates on a PAYG basis. This situation is officially projected to persist into the next century. With pension payments gradually increasing, the contribution rates are set to increase by 2 percentage points of earnings every five years (from the present level of 14.5 per cent) until 2015.

\section{Germany}

Public pensions in western Germany comprise an earnings-related scheme with general coverage for private-sector employees. Dependent spouses are insured only if they contribute on a voluntary basis. In addition, categorial schemes exist for civil servants, free professions, farmers, miners and former employees residing abroad. Accruals grow with steps of 1.5 per cent of assessed earnings per insurance year with a maximum of 60 per cent of assessed earnings. The standard retirement age is 65 , but can be reduced to 63 for 
those with 35 or more insurance years of which 15 years of contributions paid, 60 for disabled or unemployed under certain conditions regarding unemployment duration and contributions paid, and 60 for female employees under certain conditions regarding insurance and contribution years. Deferred retirement up to 67 is also possible. The 1989 pension Reform Act raises the retirement age by two years as of 2001, combined with the introduction of phased retirement (3).

\section{France}

The general scheme covers most employees in the private sector and has two tiers: the régime général providing an earnings-related basic pension and the régime complémentaire providing an earnings-related supplement. The supplementary schemes, while compulsory, are managed by the social partners rather than the central government. Categorial systems exist for public employees, miners, seamen, railroad workers, other public companies, farmers and various kinds of self-employed. The system is complemented by a means-tested old-age allowance which guarantees a social minimum for the elderly (minimum-vieillesse). Benefits are granted to those over 60, while 37.5 insurance years are required for a full pension. The rate of accrual is equal to $1 / 150$ per insurance-quarter. A full pension under the régime général amounts to 50 per cent of average earnings in the ten best years (after revaluation for general pay increases), subject to a floor and a ceiling. The régimes complémentaires provide an additional 20 per cent of earnings. There are also means-tested spouse and child supplements and, as noted earlier, a means-tested minimum provision. The standard retirement age is 60 , but early or deferred retirement is possible, and early retirement is widely claimed.

\section{Italy}

The general earnings-related scheme provides basic coverage for private sector employees. It is complemented by a means-tested social welfare programme for those who have a pension below a certain minimum or who are not eligible to the earnings-related scheme. There exist a number of categorial schemes for civil servants, railway employees, free professions and self-employed. The standard retirement age of 60 for men and 55 for women is announced to be raised by five years in the framework of a recent cost-cutting package. Pensions are payable conditional upon a minimum of 15 years of contribution. The accrual rate is equal to 2 per cent of average assessed earnings in the last five years multiplied by the number of insurance years up to a maximum of 80 per cent of assessed earnings.

\section{United Kingdom}

The general scheme (the National Insurance Scheme) combines flat-rate and earnings-related pensions, both being applicable to all private and public sector workers as well as to voluntary contributors. There is a categorial scheme for civil servants providing supplementary pensions. Both the basic flat-rate and earnings-related schemes are on an accrual basis. The standard flat-rate pension is payable to retired male contributors from age 65 and to female retired contributors from age 60 , subject to the contribution conditions 
being satisfied. People who do not claim their pensions at those ages are awarded higher pensions when they claim. For the pension to be paid at the full rate, contributions must have been paid for nine-tenths of the working life and no pensions at all are payable where contributions cover less than one quarter of the working life. A dependent spouse receives, broadly speaking, a pension of 60 per cent of her husbands pension as of age 60 .

The earnings-related scheme (SERPS) has started in 1978 and is still in the process of maturing: until 1998 nobody will have full entitlements. The earnings on which the pension is based are revalued in line with the general level of earnings, up to the year before that in which pension age is reached. The revalued earnings are then averaged over the period from age 16, or April 1978 if later, to retirement age. The pension rate will eventually be 20 per cent of average earnings as defined above, and may be regarded as accruing uniformly over the working life between age 16 and pension age. However, for those over age 16 when the scheme took effect in April 1978, the working life for this purpose is taken as the years between April 1978 and pension age subject to a minimum of 20 years. Employers who provide supplementary pensions may choose to contract their staff out to the state scheme in return for lower contributions. Individuals are also able to contract-out to the earnings-related scheme into an approved personal pension plan.

\section{Canada}

The general old Age Security scheme provides a universal flat-rate pension for all resident family heads, including means-tested guaranteed income supplements and spouse's allowances. Since 1967 two earnings-related schemes exist, the quebec Pension Plan (QPP) and the Canada Pension Plan (CPP), providing earnings-related pensions to all employed and self-employed. The QPP and CPP schemes are still in the process of phasing in. The standard retirement age is 65 for recipients of the universal pension and (at the earliest) 60 for recipients of the spouse's supplement. In the future, the contribution period required for a full pension under the earnings-related schemes (QPP and CPP, see above), will be 40 years with an accrual factor of 0.5 per cent. For the time being, however, the maximum attainable contribution period is the period between 1966 and the year in which the claimant retires, or around 25 years.

\section{Notes}

1. J.E. Duggan, "Social Security and the public debt", Public Finance, Vol. 46, No. 3, 1991, pp. 382-404.

2. N. Takayama, The greying of Japan: an economic perspective on public pensions, Kinouniya Company Ltd./Oxford University Press, 1992.

3. W. Schmäh1, "The future development of old-age security", in J. Mortensen (ed.) The Future of Pensions in the European Community, Brassey's, Brussels, 1992, pp. 39-52. 
Table 1.4. Public retirement pensions in the United States

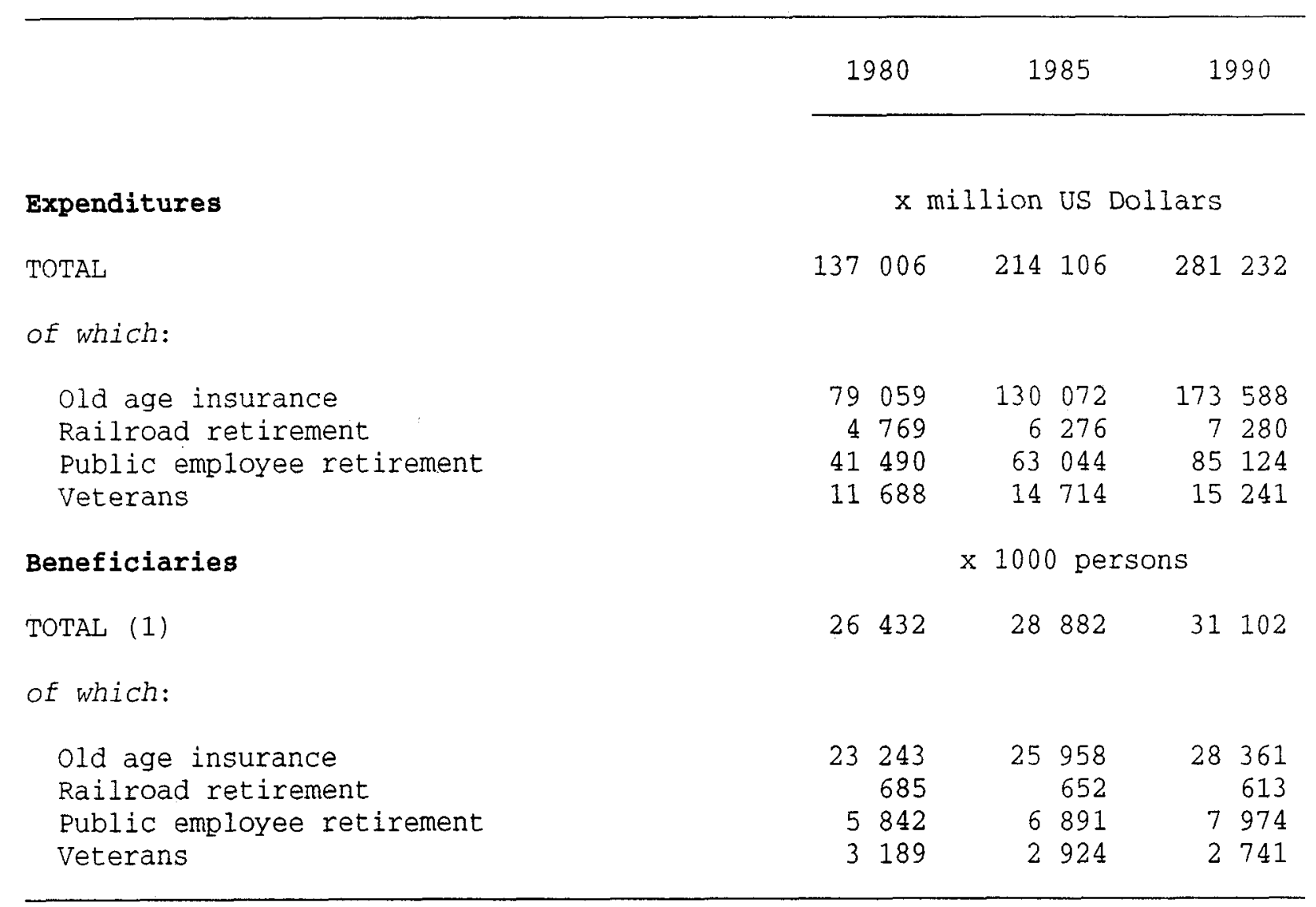

1. Old-age insurance and veterans.

Source: Submission from the United States Social Security Administration. 
Table 1.5. Public retirement pensions in Japan

\begin{tabular}{|c|c|c|c|c|}
\hline & 1980 & 1985 & \multicolumn{2}{|c|}{1990} \\
\hline Expenditures & \multicolumn{4}{|c|}{$\mathrm{x}$ billion Yen } \\
\hline TOTAL (1) & $10 \quad 470$ & 17017 & 22 & 723 \\
\hline Beneficiaries & \multicolumn{4}{|c|}{$\times 1000$ persons } \\
\hline TOTAL & 11029 & $16 \quad 221$ & 21 & 881 \\
\hline of which: & & & & \\
\hline Self-employed in the Kikumin-Nenkin scheme & 6256 & 8837 & 9 & 278 \\
\hline Salaried workers in the Kosei-Nenkin scheme & 4773 & 7384 & 10 & 519 \\
\hline Spouses in the Kokumin-Nenkin scheme & 0 & 0 & 2 & 084 \\
\hline
\end{tabular}

1. Including survivors and disability pensions.

2. 1989 instead of 1990 .

Source: Ministry of Health and Welfare, Annual Report on Health and Welfare 1991-1992, Tokyo, 1993 (forthcoming). 
Table 1.6. Public retirement pensions in Germany (1)

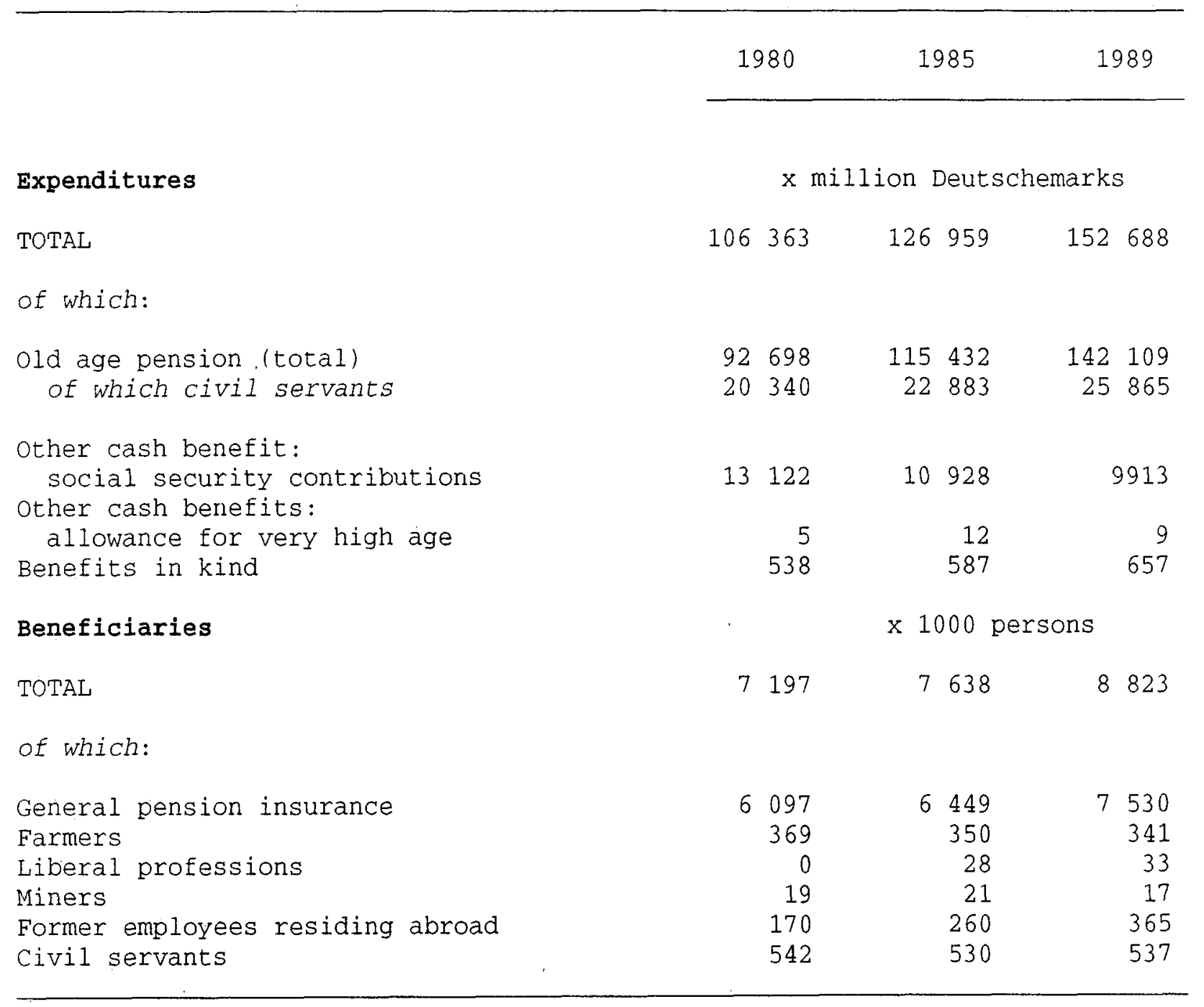

1. Western Länder.

Source: Eurostat: Digest of Statistics on social protection Europe:

Volume 1, old Age Protection. Preliminary draft, January 1992. 
Table 1.7. Public retirement pensions in France

\begin{tabular}{|c|c|c|c|c|}
\hline & 1981 & 1985 & \multicolumn{2}{|c|}{1988} \\
\hline Expenditures & \multicolumn{4}{|c|}{$\mathrm{x}$ million Francs } \\
\hline TOTAL & 257777 & 429510 & 516 & 654 \\
\hline \multicolumn{5}{|l|}{ of which: } \\
\hline Old age pension (Régime Générale) & 189092 & 306117 & 379 & 253 \\
\hline of which civil servants & 46517 & 72131 & 84 & 982 \\
\hline $\begin{array}{l}\text { Early retirement } \\
\text { of which civil servants }\end{array}$ & $\begin{array}{r}1601 \\
\\
69\end{array}$ & $\begin{array}{r}1312 \\
360\end{array}$ & 3 & $\begin{array}{r}930 \\
89\end{array}$ \\
\hline other cash benefits & 2739 & 3767 & 4 & 334 \\
\hline Benefits in kind & 323 & 770 & & 642 \\
\hline \multicolumn{5}{|l|}{ Compulsory supplementary schemes } \\
\hline (Régimes Complimentaires) & $42 \quad 432$ & 73960 & 98 & 006 \\
\hline of which civil servants & 1098 & 2159 & 2 & 573 \\
\hline Means tested welfare benefits & 21590 & 31784 & 30 & 489 \\
\hline Beneficiaries & \multicolumn{4}{|c|}{ x 1000 persons } \\
\hline TOTAL (1) & 8851 & 10720 & 12 & 137 \\
\hline of which civil servants (2) & 236 & 916 & & 952 \\
\hline
\end{tabular}

1. old age pension only.

2. In 1981 central and local government only.

Source: Eurostat op. cit. 
Table 1.8. Public retirement pensions in Italy

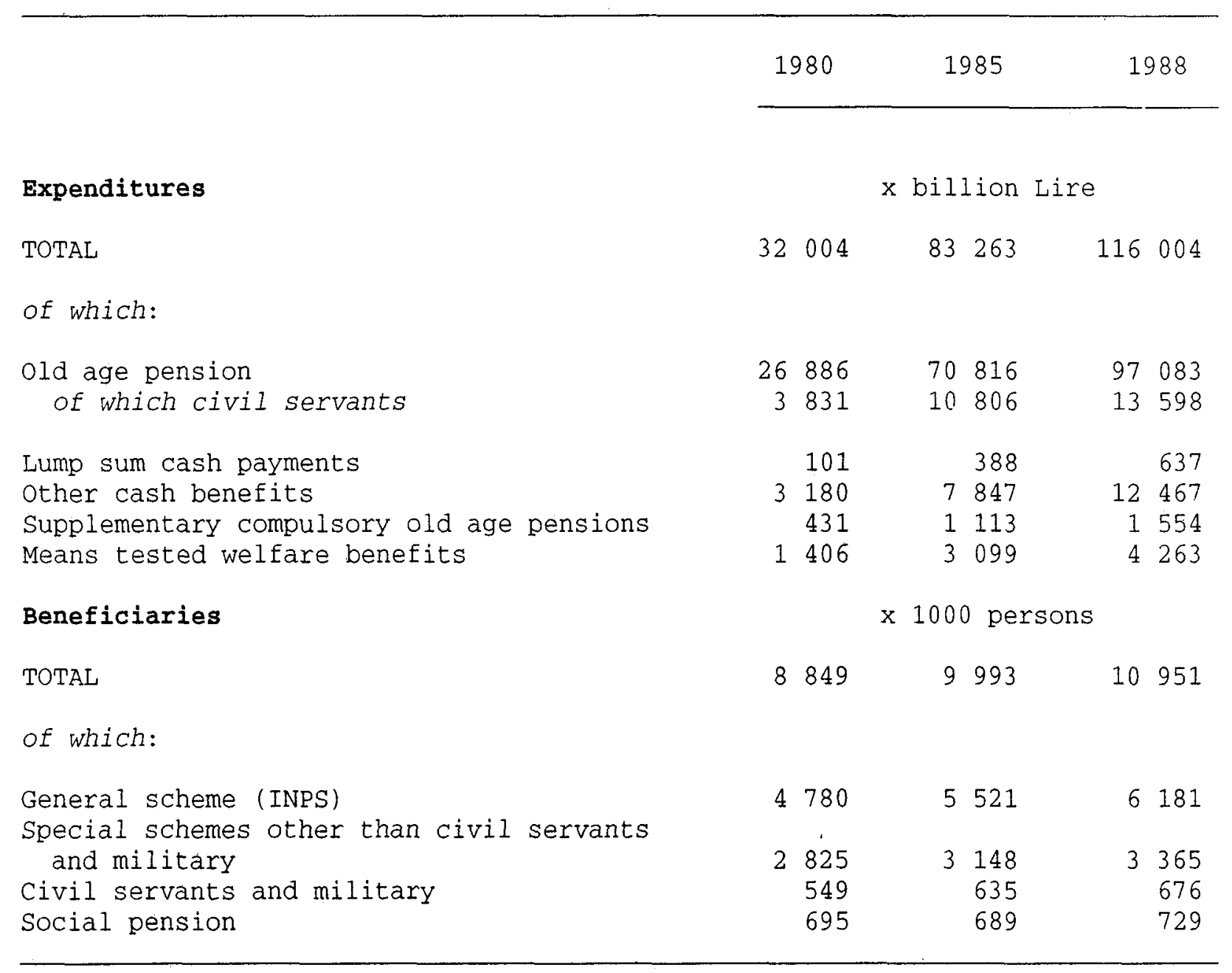

Source: Eurostat op.cit. 
Table 1.9. Public retirement pensions in the United Kingdom

\begin{tabular}{|c|c|c|c|c|}
\hline & 1980 & 1985 & \multicolumn{2}{|c|}{1988} \\
\hline Expenditures & \multicolumn{4}{|c|}{$x$ million Pounds } \\
\hline TOTAL & 16015 & 25531 & 30 & 930 \\
\hline \multicolumn{5}{|l|}{ of which: } \\
\hline All residents retirement pension & 10753 & 16871 & 19 & 639 \\
\hline Residents over 80 & 41 & 45 & & 39 \\
\hline other cash benefits & 92 & 101 & & 106 \\
\hline Supplementary pensions civil servants & 3075 & 5669 & 7 & 176 \\
\hline Means tested welfare benefits & 2054 & 2845 & 3 & 970 \\
\hline Beneficiaries & \multicolumn{4}{|c|}{ x 1000 persons } \\
\hline TOTAL (1) & 9108 & 9732 & 10 & 002 \\
\hline
\end{tabular}

1. All residents retirement pension.

Source: Eurostat op. cit. 
Table 1.10 . Public retirement pensions in Canada

\begin{tabular}{|c|c|c|c|c|c|}
\hline \multirow[b]{2}{*}{ Expenditures } & \multicolumn{2}{|c|}{1981} & 1985 & \multicolumn{2}{|c|}{1990} \\
\hline & & million & Canadian & Dolla & $\operatorname{ars}$ \\
\hline TOTAL & 10 & 663 & 16748 & 26 & 035 \\
\hline \multicolumn{6}{|l|}{ of which: } \\
\hline $\mathrm{CPP} \& \mathrm{QPP}$ Retirement Pension & & 070 & 4326 & 9 & 134 \\
\hline Guaranteed Income Supplement & & 242 & 3319 & 3 & 976 \\
\hline old Age Security & & 141 & 8858 & 12 & 705 \\
\hline Spouses Allowance/Spouses SP & & 192 & 223 & & 207 \\
\hline Unemployment Insurance Retirement Benefits & & 18 & 22 & & 13 \\
\hline Beneficiaries & \multicolumn{5}{|c|}{ x 1000 persons } \\
\hline TOTAL (1) & & 388 & 2663 & 3 & 133 \\
\hline \multicolumn{6}{|l|}{ of which: } \\
\hline$C P P \& Q P P$ Retirement Pension & & 680 & 2211 & 3 & 234 \\
\hline Guaranteed Income Supplement & & 245 & 1297 & 1 & 359 \\
\hline old Age Security & & 303 & 2569 & 3 & 006 \\
\hline Spouses Allowance/Spouses SP & & 85 & 93 & & 127 \\
\hline
\end{tabular}

1. Old age security and spouses allowance only.

Source: Submission from Statistics Canada/Statistique Canada. 


\section{Annex 2}

\section{The Valuation of Pension Schemes}

\section{Methods used in the private sector}

There appears to be no unique method used for the valuation of pension schemes. The principal methods used in the private sector are:

-- Accrued to date. This method computes the present value at the date of calculation of pensions to be paid in the future on the basis of accrued rights. It does not take account of possible new obligations or future income -- from contributions or from interest. This present value is then compared with the value of the fund's assets to see if minimum funding requirements are satisfied.

- Closed system. This method assumes that the fund continues its existence until the last current contributor dies, while no new entrants are allowed in the scheme. The future contributions of existing members is allowed for, as well as the accrual of new rights of these members, but not the contributions and accruals of future members even when these are certain to be admitted.

- New entrant method. The present value of the typical new entrant's future stream of pension receipts is calculated on the basis of an average career assumption. Contributions are then set to ensure that the present value is zero. This system is typically used as a complement to the closed system.

-- Open system. The present value of all estimated future pension payments -- including those of new entrants -- is compared with present assets. If the contribution rate is set at the new entrant rate, the relationship between assets and liabilities for the open system and the closed system are exactly the same (as the net present value for new entrants would be zero).

Each of these methods has its own advantages and drawbacks. The "accrued to date" method, which is the most widely but not exclusively used for the purpose of measuring a fund's future liabilities and solvency, has the advantage that it bases its estimates on available historical information. Indeed, when calculations are made the existing assets of the fund and the existing accruals are all known. At the same time, however, it falls short of producing a reliable estimate of the contribution rate required to sustain the fund when new accruals and new entrants are allowed for. The "open system" method - - which encompasses the "closed system" and "new entrants" methods -does provide the necessary information to make such an estimate. It may hence be appropriate to employ both methods, making use of the advantages of each of 
them. Such an "eclectic" approach underlies the methodology that has been developed for this exercise.

\section{Valuation according to the "accrued-to-date" method}

The valuation of the pension systems in the countries under consideration according to the "accrued-to-date" method referred to in Section II of the main text, is based on a stylised model or "archetype" pension scheme, rather than using details of the pension scheme for each country. This method attempts to measure the present value of pensions already in payment and those pensions that would have to be paid if there were no new entrants to the scheme. The pension scheme has, for the purposes of this calculation, been closed. This stylised model has been calibrated on the 1990 data for the countries under consideration, and has served as the basis for all subsequent estimates and projections. The approach can be summarised as follows:

-- The population of a country is broken down into five-year age groups. The pension benefits paid to any age group at pension age at any future point in time is determined by i) the size of the population in this age group still alive; ii) the proportion of people in this age group eligible for a pension benefit; and iii) the average per capita pension to which persons in this age group are entitled given their number of years of contribution.

-- The standard retirement age is 60 , and the number of years of contribution required for a full pension is 40 . These rules apply to workers and other persons alike. The pension entitlements accrue at a constant rate of $1 / 8$ every five years. There is no minimum contribution period required for eligibility.

The implications of these assumptions can best be illustrated with the help of the graphical representation in Figure 2.1. The figure shows that in this closed system pensions are paid exclusively to persons of 60 years of age and older. Moreover, all benefits allocated to these persons cover full entitlements corresponding to 40 contributions years (the shaded area). The oldest age group not yet in retirement in 1990, however, has accrued rights up to the equivalent of 35 to 40 years, and would thus be entitled to a reduced pension equal to $7 / 8$ times a full pension when they retire in 1995. Similarly, the 50 to 55 age group has entitlements up to the equivalent of 30 to 35 contribution years, and is entitled to $6 / 8$ times the full pension when they retire in 2000, etc. Under these assumptions, by the year 2010 all age groups with full entitlements have died, and by the year 2050, no more partial pensions are claimed.

The system described above is no more than an empty "shell" which has to be filled with real data for the countries under consideration. This can be done in various ways, but here the following choices have been made:

-- All public transfers paid to old-aged persons in 1990 -- flat-rate, earnings-related and means-tested benefits -- have been considered as pension expenditure subject to accruals according to the rules formulated above (A). Similarly, all recipients of these transfers 


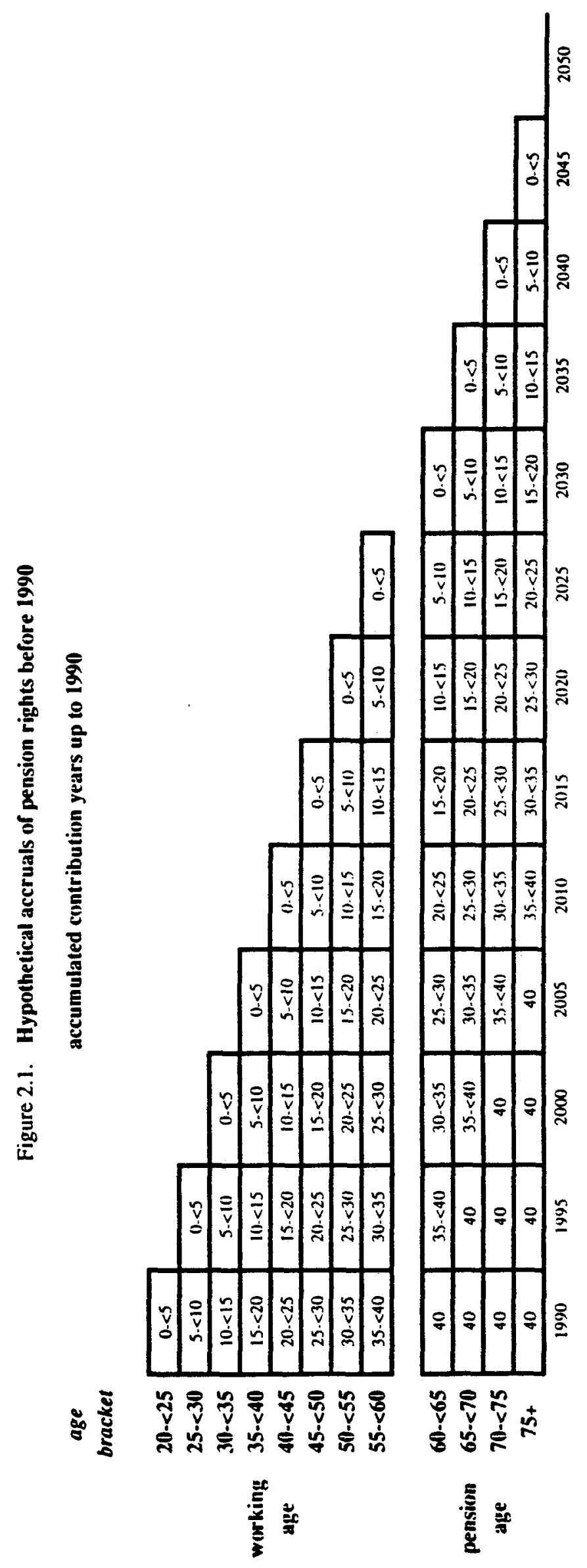


have been considered as persons eligible to this general stylised old-age pension scheme (B). The resulting full pension rate in 1990 is equal to the ratio $A / B$.

-- Given that the actual pension entitlements and ages differ across countries and do not exactly correspond with the stylised system, the number of recipients of old-age transfers ( $B$ above) does not necessarily match the number of people of age 60 and over (C). The ratio $B / C$ in most countries is below unity and will henceforth be called the eligibility ratio. The eligibility ratio has been calculated for the base year and is held constant over the projection period (1990-2050) for each age group.

-- The projection of the number of persons at pension age (C) per age group is taken from the most recent edition of the World Population Projections of the World Bank.

The evaluation of the pension rate applied to the various age groups in the projection is made in two steps. First, an assumption is made as to the equivalent of a full pension rate an average beneficiary is entitled to once he enters retirement (the entry level). Second, an assumption has to be made as to the development of a cohort's pension rate over its retirement age. The mechanisms that have been assumed are the following:

-- The entry level of the pension rate is projected to grow at the same rate as projected real earnings and real output per worker (1 per cent per annum in the United States, 2 per cent per annum in the other countries). This approach is the equivalent of a system where the assessed earnings on which the pension rate is based is uprated with the overall growth of earnings. In the United Kingdom and Canada, however, a faster rate of increase of the entry level has been assumed to reflect the impact of the phasing-in of earnings-related schemes: 3.3 per cent per year until 2000 and 2.9 per cent per year until 2005, respectively (1).

-- The pension rate is subsequently held constant in real terms for the rest of a cohort's life. This is the equivalent of a system where the pension rate over the retirement age is uprated in line with overall inflation.

-- The data for total pension expenditure and the number of beneficiaries are shown in Annex Tables 1.4 to 1.10 . The number of beneficiaries shown in these tables may include some double counting. This will lower the average pension but raise the eligibility ratio. The projection of expenditure will not be affected by this double counting as over-counting beneficiaries lowers the average pension.

The method of pro-rating benefits involves a certain inconsistency with the design of some pension schemes, especially where there is a guaranteed minimum pension that is independent of the contribution record. Similarly means-tested benefits are independent to contribution records. 

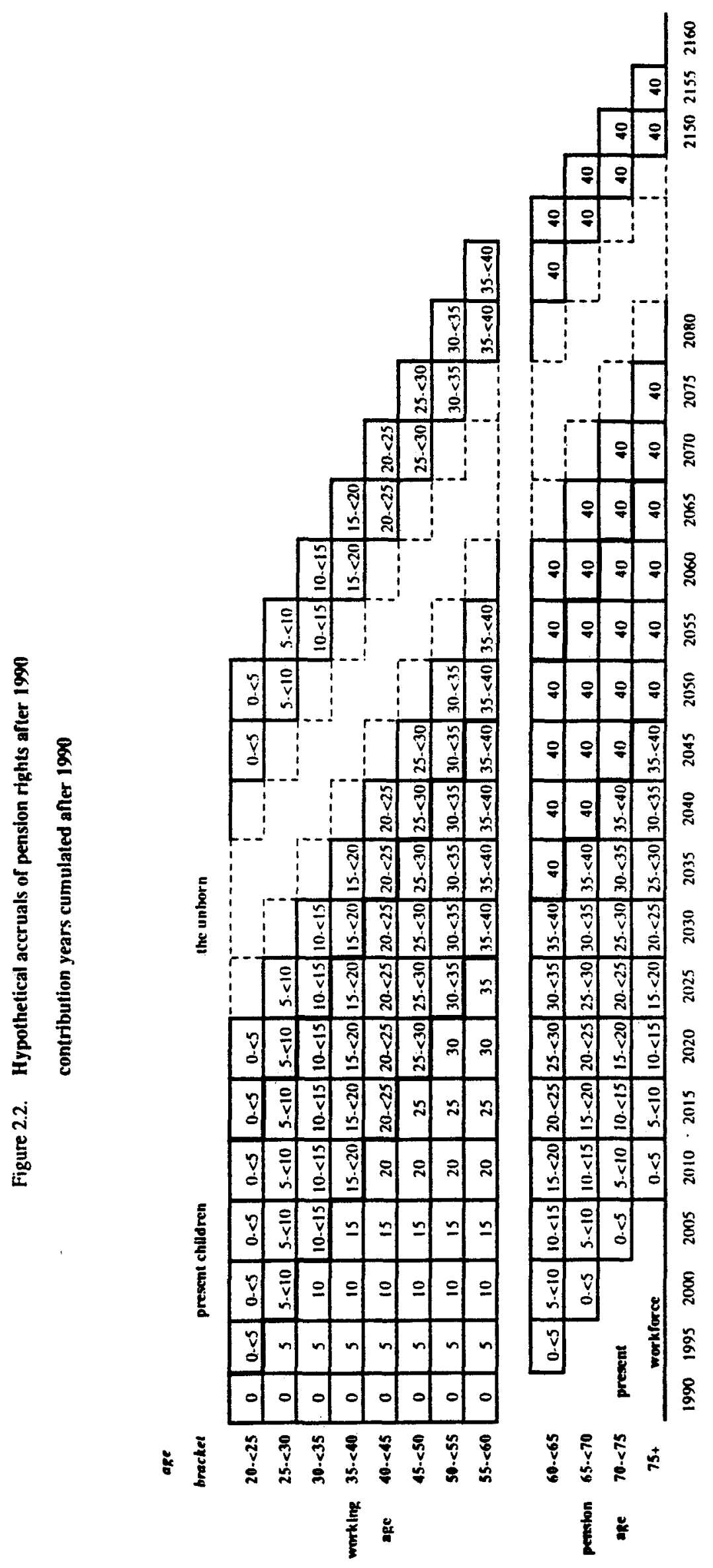


\section{Valuation according to the "open system" method}

The evaluation of pension systems applying the "open system" method referred to in section IV of the main text is based on the same stylised approach discussed above. This, again, can best be illustrated with the help of a schematic presentation, as in Figure 2.2. The upper half of the figure shows how pension rights are assumed to accrue over the working life of cohorts that will accrue rights after 1990. A distinction has been made between cohorts which belong to the present workforce and later cohorts. The present workforce has already accrued rights in the past, but will also accrue additional rights in the future. In 1990 these additional rights are zero, but by 1995 the equivalent of five more contribution years have been accrued, by 2000 ten more years, etc. As concerns the future workforce, consisting of children that were already born in 1990 and those not yet born in 1990, new rights gradually build up reaching a peak of 40 years when the generation reaches retirement age.

In order to estimate the distribution of pension contributions across generations, an assumption has to be made on the development of earnings per cohort over time, in line with some typical career-earnings pattern. For the sake of simplicity, the same career-earnings pattern has been assumed for all countries and for all times. Real earnings are assumed to grow by 2 per cent per year between the ages of 20 and 50 and are kept constant thereafter until retirement age is reached. Real pension contributions are assumed to develop proportionally to this earnings pattern. Assuming that overall earnings grow in line with output per worker, the contributions to be attached to each cohort at each point in time, the equivalent of the cells in the upper half of Figure 2.2, are determined.

\section{The inter-generational redistribution of wealth}

The methodology discussed above allows for an evaluation of the distribution of new pension entitlements and contributions across generations of beneficiaries. Four generations are distinguished: the present retired in 1990, the present workforce (with a further breakdown into accruals after and accruals before 1990), the children that were living in 1990, and the unborn in 1990. For each of these generations estimates are made of their entitlements, their contributions (if applicable) and their resulting net entitlements. This type of presentation is known as a generational account (Table 2.1). A positive number in such an account implies a net debt of the government to a specific generation and hence as a net transfer of wealth to that generation. Similarly, a negative number represents a net debt of a particular generation to the government and hence a net transfer of wealth from that generation. Generational accounts differ fundamentally from cash accounts in that they measure transfers over a life-time rather than at a given point in time. A PAYG pension scheme typically involves transfers between generations at a point in time (as measured by cash accounts) -- but this does not automatically generate any net transfer over a generation's life-time (as measured by generational accounts).

The most striking result of the calculations is that in all but one of the countries under consideration, the net liability of governments is primarily the reflection of pensions to be paid to existing retirees or 


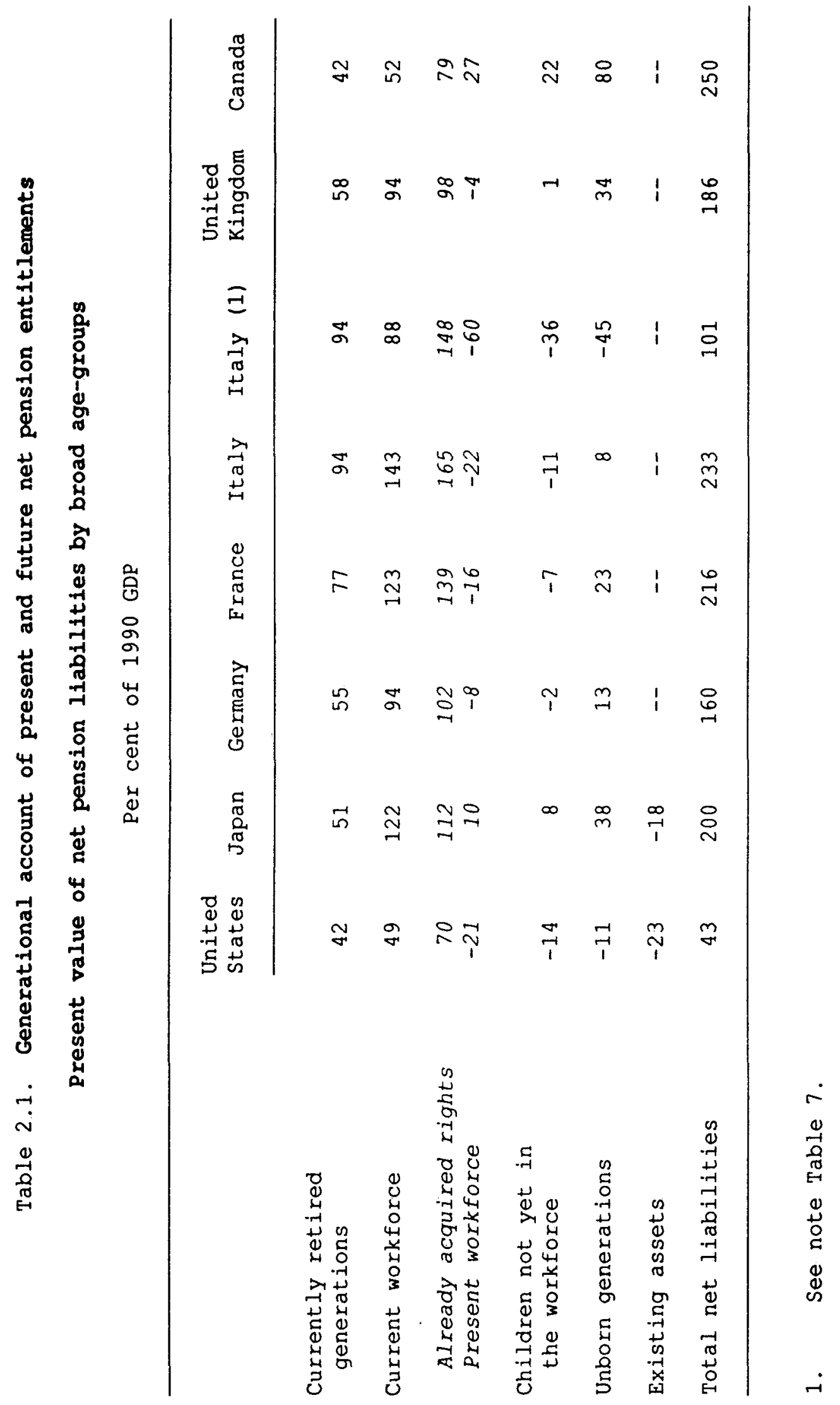


obligations resulting from the past contributions of the existing labour force. only in Canada are promises to future generations a significant part of current net liabilities. Looking at the present value of net pension liabilities arising from new rights (as in II in Table 8), countries can be split into three distinct groups:

-- Those where if present contribution rates were maintained forever, accruals of contributions would broady match new accruals of pension rights (while leaving the existing accruals unfinanced). France and Germany were broadly in this situation.

- There are those countries where rights for new generations were accruing faster than contributions. Japan, the United Kingdom and Canada were in this case primarily due to the fact that contributions in these countries do not yet reflect the steady state of a maturing pension scheme.

-- Finally, there are those countries where future generations are being called upon to transfer wealth to current generations. The United States and Italy were in this situation in 1990.

Given the implementation lags that have been assumed, the effects of the announced increase in the pensionable age by five years in Italy would primarily affect the younger age brackets of the present workforce (with low accruals to date) and the future workforce. Almost the entire reduction in future entitlements and the associated reduction in government indebtedness, about 100 per cent of 1990 GDP, is concentrated among these groups. The measure can thus be analysed as an attempt to transfer wealth from younger generations to older ones.

\section{Note}

1. As for the United Kingdom, the implied additional increase in pensions is applied to the age-brackets of 65 and older only. The estimates are based on the Report by the Government Actuary on the Second Quinquennial Review under Section 137 of the Social Security Act, National Institute Fund Long Term Financial Estimates, HMSO, London, 1990. As for Canada, the estimates are based on information submitted by Statistics Canada/Statistiques Canada and in OECD, Reforming Public Pensions, Paris, 1988 . 
Annex 3

Financing Options for Pension Schemes

This annex reviews the main features of alternative financing regimes discussed in Section $V$ of the main text, on the basis of an illustrative case (Figure 3.1).

\section{Alternative financing required}

PaY-As-You-Go

If Pay-As-You-Go financing were to be extended into the future (or reintroduced, as appropriate), contributions and benefits in any year would have to match, even if expenditures would rise to unprecedented heights (Figure 3.1, upper-left panel). In the illustrative case, this would mean that the contribution ratio would have to increase from around 10 per cent at present, to over 20 per cent when the old-age dependency ratio stabilises or reached its peak in around 2030-2040. Since the old-age dependency ratio will rise in the coming decades, Pay-As-You-Go financing requires a redistribution of wealth from future to present generations.

\section{Quasi-funding}

Countries which so far have relied on Pay-As-You-Go financing, could switch to a quasi-funded system (1). They could do so through a once-and-for-all increase in their contribution ratio, allowing a fund to cumulate which is to be depleted subsequently (Figure 3.1, upper-right panel). In the illustrative case, the fund would reach its maximum size in the second decade of the next century and then be gradually exhausted. An advantage of funding is, that the contribution ratio would rise to a level which is well below the maximum required under Pay-As-You-Go financing, as the government could benefit from interest returns. At the same time, a funded regime would involve significantly less redistribution of wealth from future to present generations implied by a Pay-As-You-Go regime. From a macroeconomic point of view, a switch to funding may have favourable long-run effects, such as an increase in the savings rate and an associated decline in real interest rates. Such an effect is, however, not assumed in the projections.

\section{Reduced earnings-related upratings}

Governments could decide to limit the degree to which assessed earnings, on which pension rates of pensioners who enter retirement are based, are brought into line with overall earnings. In the illustrative case, if the real growth in pension rates were limited to about half the growth of real overall earnings, this would be broadly sufficient to balance the system. Sustainment 
Figure 3.1. The profile of pension benefits and contributions under various financing regimes - an illustrative case

As a percentage of GDP

Surplus Deficit
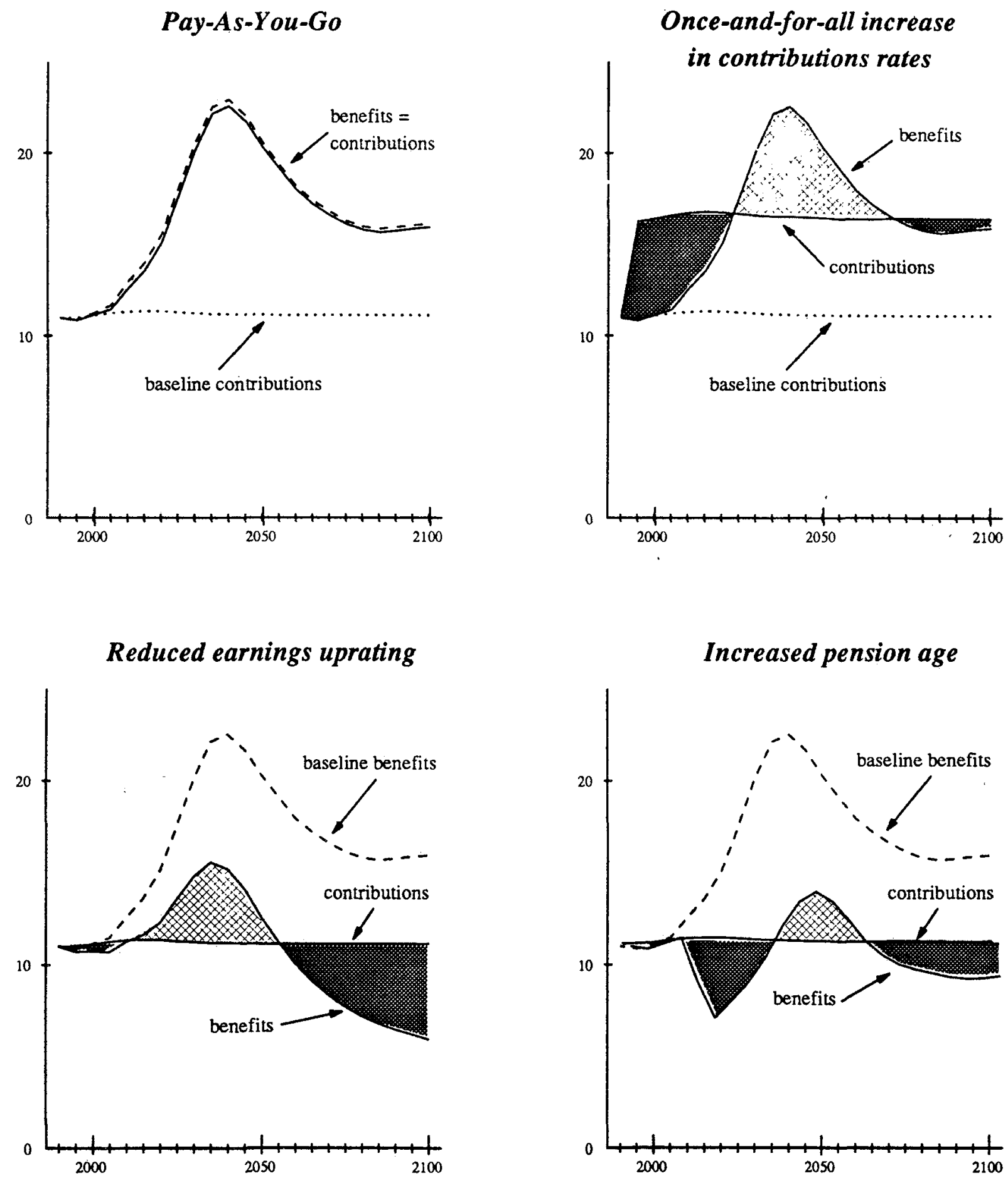
of such a regime implies that the ratio of pension benefits to GDP would decline indefinitely (Figure 3.1, lower-left panel). Moreover, the system would run deficits early on, and surpluses in the very long run to repay the accumulated debt. Hence, a pronounced shift of the pension burden to future generations would occur, comparable to that implied by Pay-As-You-Go financing. At the same time, the implicit rate of return on pension savings would become negative. Such an outcome would probably not be feasible as future generations are not likely to be willing to sustain it.

\section{Increase in the pensionable age}

Alternatively, governments could raise the pensionable age to a level where the system is in financial balance. Such a regime would have some characteristics in common with a once-and-for-all increase in contributions. However, as the increase is phased-in, the surplus in the scheme occurs later. As a result, in the long run, contributions have to exceed benefits by a larger margin than in the case of an increase in contributions (Figure 3.1, lower-right panel). Initially, the system would run small deficits, as the old-age dependency ratio increases and implementation lags limit the initial effects of the increase in the pensionable age. But once the impact of the increase in retirement age becomes fully effective, a surplus will emerge. The system would run into deficit again, however, when the old-age dependency ratio is in its highest range. Once the impact of the retirement of the baby-boom generation has petered out, a relatively small surplus could be maintained in order to service the debt that has been cumulated in the initial phase. This option, in common with the reduced earnings-related upratings regime, is based on the assumption that the contribution ratios would be maintained at present levels. It would also imply a redistribution of wealth from future to present generations of about the same magnitude as an increase in contributions, but less than under reduced-earnings related uprating or Pay-As-You-Go financing.

\section{Notes}

1. The term quasi-funding rather than funding is applied as in truly funded schemes the fund would typically be created before rights accrue and not after they have already accrued. 


\section{Annex 4 \\ Simulation of the Alternative Financing Options}

The results for the four options discussed in Annex 3 are summarised in a set of generational accounts (Tables 4.1 to 4.4 ). The following assumptions lay behind these results:

-- In the simulation of a PAYG regime, expenditure patterns remain unchanged compared to the baseline, but the contribution ratio in any year has been changed such as to make it equal to the expenditure ratio. The associated increase in the contribution rates per age group are in proportion to their share in total contributions in the baseline.

-- In the case of funding, a once-and-for-all increase in the contribution ratio is iterated, until a point is reached where the present value of future surpluses and deficits over the projection period is zero. Again, the increase in contribution rates per age group is proportional.

- A similar iteration procedure is followed to find the real-earnings elasticity producing a zero present value of deficits and surpluses.

-- The required increase in the pensionable age is found for generations born between 1945 and 1950 by raising the retirement age by steps of one year. In a first round, the retirement age for those aged between 60 and 64 is varied as of the year 2010 (when the first post-war cohort is retired) in order to attain a zero net present value. If the exclusion from retirement of the entire 60-64 age bracket in the period 2010-2015 is still insufficient to attain financial balance, the calculation is extended to subsequent age brackets, until financial balance is reached. 


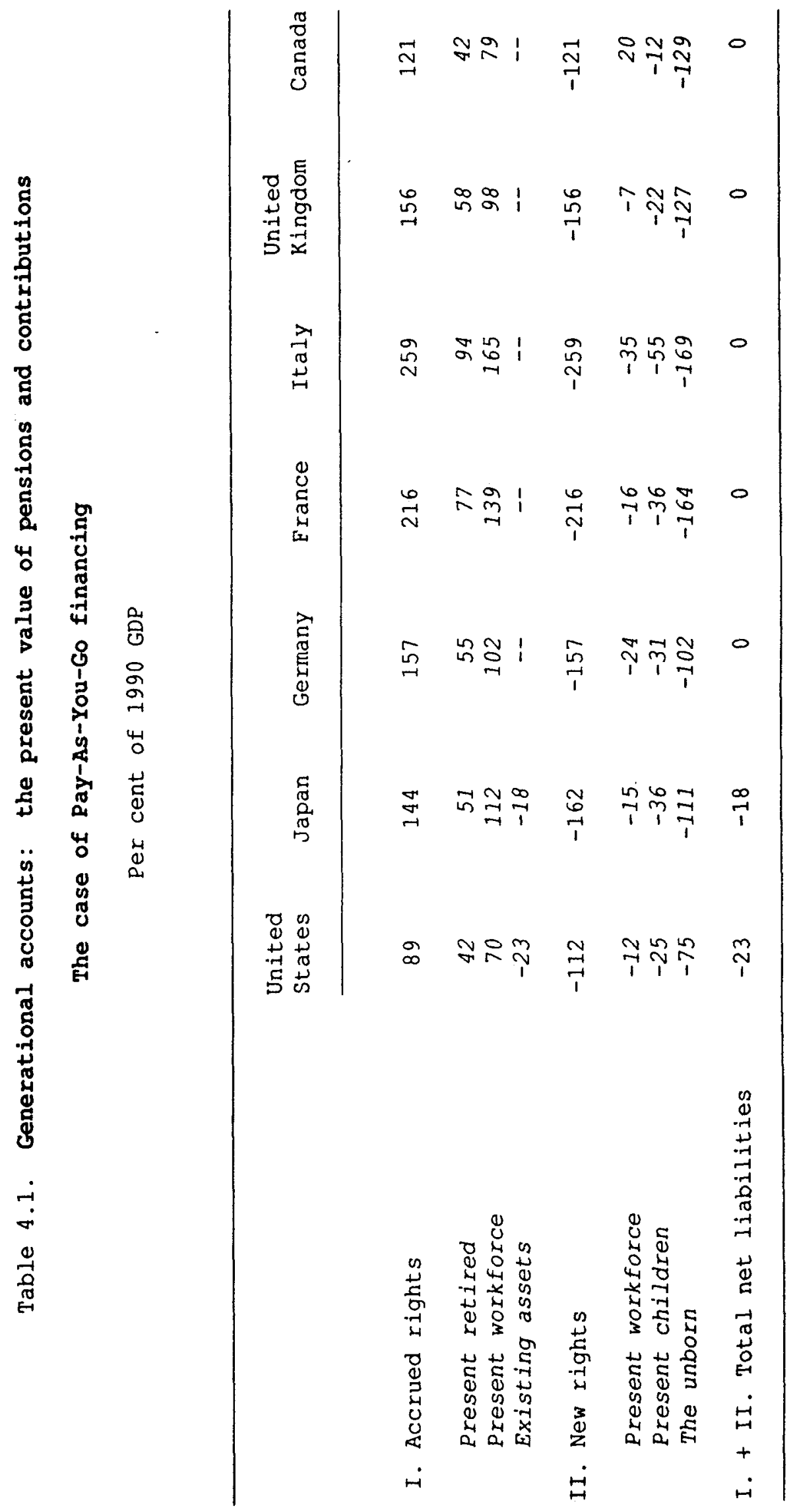




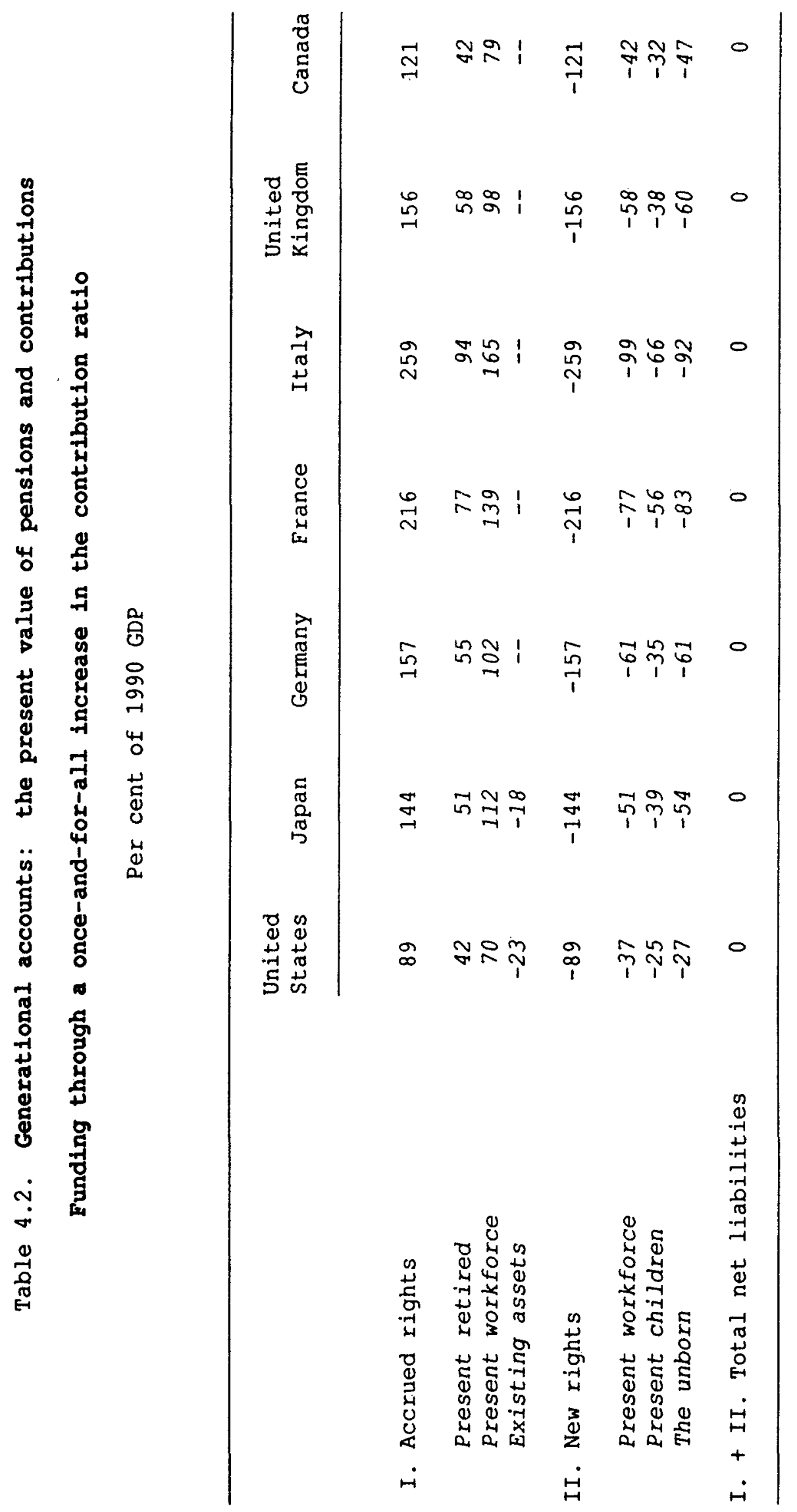




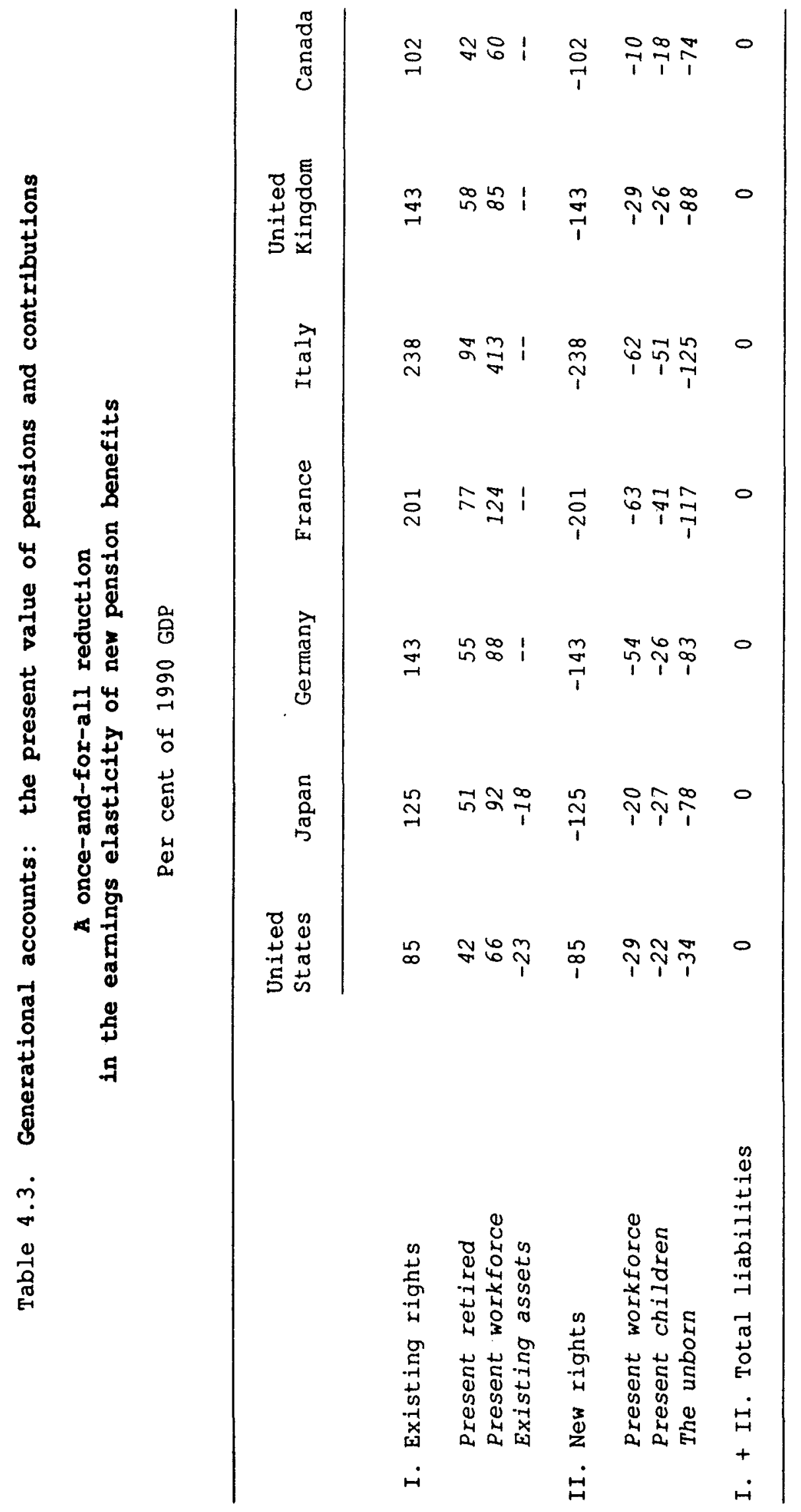




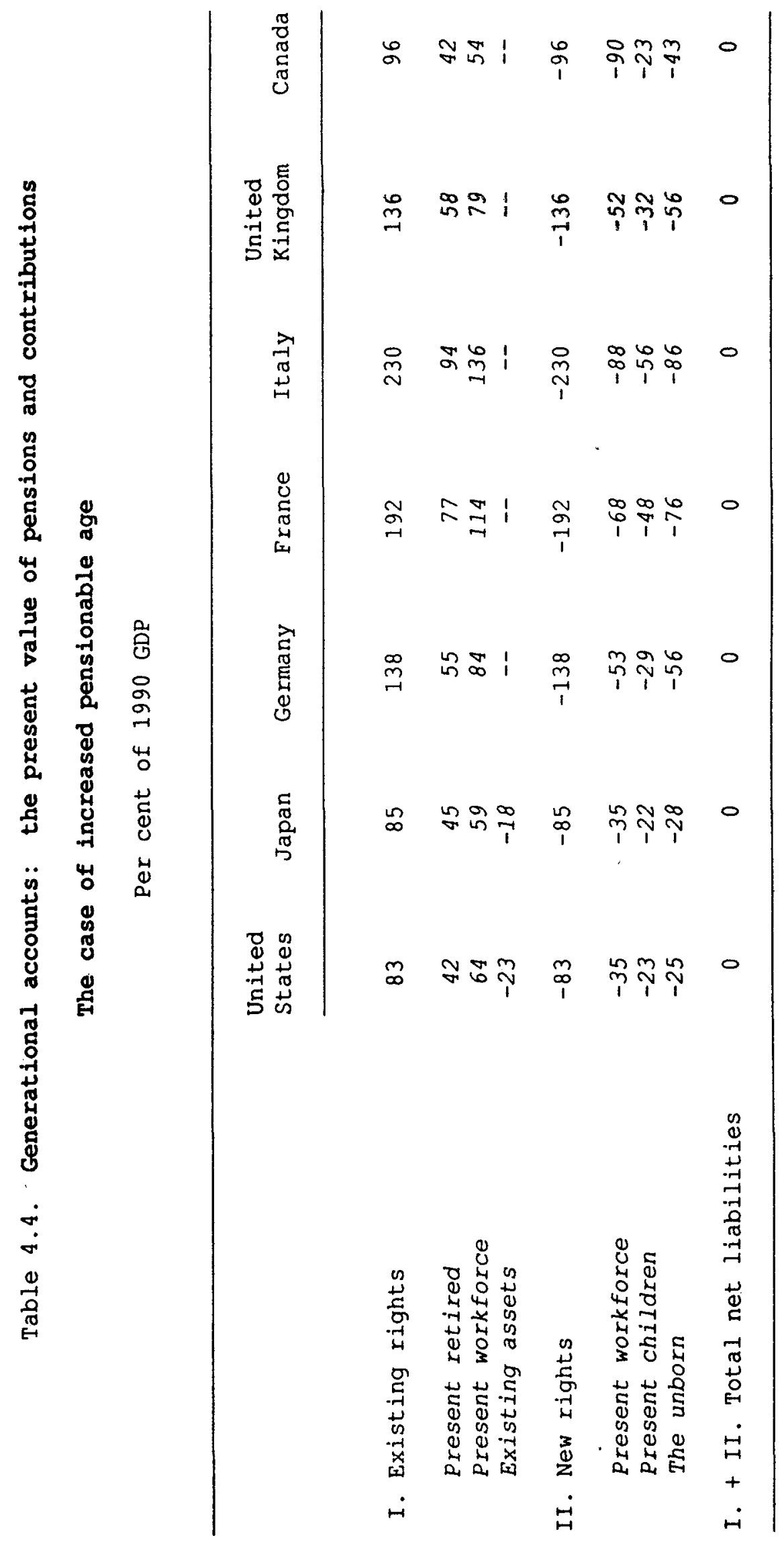




\section{ECONOMICS DEPARTMENT}

\section{WORKING PAPERS}

A complete list of Working Papers is available on request.

141. The Distribution System in Sweden (October 1993)

Sören Wibe

140. The Distribution Sector in the United Kingdom (October 1993)

John A. Dawson

139. The Italian Distribution System (October 1993)

Luca Pellegrini and Angelo M. Cardani

138. The French Distribution Industry and the openness of the French Economy (October 1993)

Patrick Messerlin

137. The German Distribution System (October 1993)

Josef Lachner, Uwe Chr. Täger, Gunter Weitzel

136. A Study of the Distribution System in Japan (October 1993) Masayoshi Maruyama

135. An analysis of the U.S. Distribution System (October 1993)

Roger $\mathrm{R}$. Betancourt

134. Market Structure, International Trade and Relative Wages (October 1993) Joaquim Oliveira Martins

133. The economic analysis of institutions and organisations -- in general and with respect to country studies (September 1993)

oliver E. Williamson

132. High and Persistent Unemployment: Assessment of the Problem and its Causes (September 1993) Jørgen Elmeskov

131. Centralisation of Wage Bargaining and Macroeconomic Performance: $A$ survey (September 1993) Lars Calmfors

130. Unemployment and Labour Force Participation -- Trends and Cycles (June 1993) Jørgen Elmeskov and Karl Pichelmann

129. Trends and cycles in Labour productivity in the Major oECD Countries (June 1993) Giuseppe Nicoletti and Lucrezia Reichlin

128. International integration of financial markets and the cost of capital (March 1993) Mitsuhiro Fukao

127. The International spillovers of capital income taxation: an applied general equilibrium analysis (January 1993)

François Delorme, Lawrence H. Goulder and Philippe Thalmann 
126. The future of capital income taxation in a liberalised financial environment (January 1993)

David Carey, Jean-Claude Chouraqui and Robert P. Hagemann

125. Global effects of the European carbon tax (December 1992)

Giuseppe Nicoletti and Joaquim Oliveira-Martins

124. The Chinese Economic Area: Economic Integration Without a Free Trade Agreement

(July 1992) Randall Jones, Robert King and Michael Klein

123. New Issues: The OECD'S Second Survey of the Macroeconomic Costs of Reducing $\mathrm{CO}_{2}$ Emissions

(July 1992) Peter Hoeller, Andrew Dean and Masahiro Hajafuji

122. Costs of Reducing $\mathrm{CO}_{2}$ Emissions: Evidence from Six Global Models

(July 1992) Andrew Dean and Peter Hoeller

121. Results for the OECD Comparative Modelling Project from the Whalley-Wigle Model (July 1992)

John Whalley, University of $w$. Ontario, and Randall Wigle, Wilfrid Laurier University

120. OECD Indicators of International Trade and Competitiveness

(July 1992) M. Durand, J. Simon and C. Webb

119. Les indicateurs de compétitivité et de commerce internationaux de l'OCDE (July 1992) M. Durand, J. Simon and C. Webb

118. The Cost of Reducing $\mathrm{CO}_{2}$ Emissions: A Comparison of Carbon Tax Curves with GREEN (July 1992)

J. Oliveira-Martins, J.M. Burniaux, J. Martin, G. Nicoletti

117. The Costs of Reducing $\mathrm{CO}_{2}$ Emissions: A Comparison of Carbon Tax Curves with GREEN (June 1992)

J. Oliveira-Martins, J.M. Burniaux, J. Martin and G. Nicoletti

116. GREEN: A Multi-sector, Multi-region, Dynamic General Equilibrium Model for Quantifying the Costs of Curbin $\mathrm{CO}_{2}$ Emissions: A Technical Manual (May 1992)

J.M. Burniaux, J. Martin, G. Nicoletti and J. Oliveira-Martins

115. The Costs of Reducing $\mathrm{CO}_{2}$ Emissions: Evidence from GREEN

J-M Burniaux, J. P. Martin, G. Nicoletti and J. Oliveira Martins

114. Carbon Taxes and CO2 Emissions Targets: Results for Reducing Carbon Emissions E. Lakis Vouyoukas, IEA

113. Use of the Edmonds-Reilly Model to Model Energy-Related Greenhouse Gas Emissions

D.W. Barns, J.A. Edmonds and J.M. Reilly, Pacific Northwest Laboratory, Washington, D.C. 



\title{
ECONOMICS DEPARTMENT
}

\section{WORKING PAPERS}

\begin{abstract}
This series of Working Papers is designed to make available, to a wider readership, selected studies which the Department has prepared for use within OECD. Authorship is generally collective, but main individual authors are named. The Papers are generally available in their original language, English or French, with a summary in the other.

The views expressed in this paper are those of the author(s) and do not necessarily reflect those of the OECD or of the governments of its Member countries.

Comment on the Papers is invited, and may be sent to OECD Economics Department, 2 rue André Pascal, 75775 Paris Cedex 16, France. Additional copies of the Papers, on a limited basis, can be forwarded on request.
\end{abstract}

